\title{
Cycles of Civilization in Northern Mesopotamia, 4400-2000 BC
}

\section{Citation}

Ur, Jason. Forthcoming. Cycles of Civilization in Northern Mesopotamia, 4400-2000 BC. Journal of Archaeological Research.

\section{Published Version}

http://www.springerlink.com/content/u423066748kl93v5/?

$p=74 d f f 5 d 53 b d 648 b 9 a 263 e b 810 f d 1370 d \& p i=1$

\section{Permanent link}

http://nrs.harvard.edu/urn-3:HUL.InstRepos:3210514

\section{Terms of Use}

This article was downloaded from Harvard University's DASH repository, and is made available under the terms and conditions applicable to Other Posted Material, as set forth at http:// nrs.harvard.edu/urn-3:HUL.InstRepos:dash.current.terms-of-use\#LAA

\section{Share Your Story}

The Harvard community has made this article openly available.

Please share how this access benefits you. Submit a story.

\section{Accessibility}


Cycles of Civilization in Northern Mesopotamia, 4400-2000 BC

Jason A. Ur ${ }^{1}$

Suggested running head: "Cycles of Civilization in Northern Mesopotamia" (46 characters including spaces)

Manuscript submitted to the Journal of Archaeological Research, 14 August 2009

${ }^{1}$ Department of Anthropology, Harvard University, 11 Divinity Avenue, Cambridge, MA 02138

USA. (617) 495-8920. jasonur@fas.harvard.edu 
Abstract:

The intensification of fieldwork in northern Mesopotamia, the upper region of the TigrisEuphrates basin, has revealed two cycles of expansion and reduction in social complexity between 4400-2000 BC. These cycles include developments in social inequality, political centralization, craft production and economic specialization, agropastoral land use, and urbanization. Contrary to earlier assessments, many of these developments proceeded independently from the polities in southern Mesopotamia, although not in isolation. This review considers recent data from excavations and surveys in northern Iraq, northeastern Syria, and southeastern Turkey with particular attention to how they are used to construct models of early urban polities.

Key words: Mesopotamia, complex society, urbanism, collapse 


\section{Introduction}

Over a span of more than two millennia, northern Mesopotamia witnessed the emergence of urban complex society, its collapse and rebirth, and a further episode of collapse. This time span (ca. 4400-2000 BC) has been intensively studied by archaeologists over the last two decades, largely because of twin push (the closure of Iraq to foreign archaeology) and pull (salvage campaigns in advance of dam projects) forces. As a result, what was once considered to be the periphery of early urbanism and state formation in southern Mesopotamia (modern southern Iraq) has emerged as a region of interest in its own right. In many ways we now have a superior understanding of major social developments in the north (e.g., urbanism, craft production, agricultural and pastoral organization, the development of the landscape) than we do for the south, and improvements in chronology have revealed that many aspects of social complexity that were once assumed to have been imported from southern Mesopotamia have earlier and entirely indigenous origins.

This review describes the development of social complexity from $4400 \mathrm{BC}$ to the collapse of urban society at the end of the 3rd millennium BC in northern (or upper)

Mesopotamia, defined here as the Tigris and Euphrates River valleys and the plains and steppe between them that fall today in northern Iraq, northern Syria, and southeastern Turkey (Fig. 1). Much archaeological research in the region, and in the Near East in general, adopts a culture historical approach that emphasizes typology and the development of sequences of material culture; here the emphasis is on anthropologically oriented research published since 1990. Geographically, the focus is on the river valleys and alluvial plains of Syria, and particularly the Upper Khabur basin of Hassake province. Occasionally I refer to sites beyond northern Mesopotamia proper when they are relevant to the discussion, particularly the western Syrian 
cities of Ebla and Umm al-Marra; the important Syrian city of Mari, on the Euphrates near the Iraqi border, is largely southern Mesopotamian in orientation and will be not be discussed (although see Margueron 2004).

In Mesopotamian archaeology generally, social complexity is described through the nature of interactions between individuals and groups. At times of greater social complexity, Mesopotamian societies were characterized by an expansion in the intensity and diversity of relations. Most scholars understand this expansion to result from the rise of class or residentially-based forms of social identification at the expense of kin-based identities, a shift which enabled new political, religious, and economic institutions (normally described as palaces or temples) employing new administrative technologies, greater craft specialization, expanded interregional exchange, and population nucleation. These latter aspects have material manifestations that can be identified in the archaeological record. The kinship-class opposition has been a durable one and is often explicitly or implicitly placed as the basis for the changes in most of these variables, but one that has begun to be challenged (Schloen 2001), although as yet these challenges have not been widely accepted.

Cycles of social complexity are here identified by the appearance and disappearance of such variables. In Late Chalcolithic and Bronze Age Mesopotamian history, many of them have a tendency to emerge or disappear simultaneously, in packages that can be used to define Mesopotamian civilizations, to employ a problematic but useful term. These cycles should not be seen as stable and recurring equilibrium states to which societies could return by crossing some evolutionary threshold. The social variables that define them might be superficially similar (e.g., large population agglomerations we label as "cities," a variable dealt with in particular 
detail below) but they encompass a range of variation, both within the time frame considered here and in subsequent phases of northern Mesopotamian history.

Geographical zones in northern Mesopotamia

Northern Mesopotamia encompasses a number of geographically and climatically diverse subregions. These environments presented limitations and opportunities for human communities. These subregions have also structured archaeological research.

The major structuring elements are of course the Tigris and Euphrates Rivers, which arise in the Taurus Mountains of southeastern Anatolia in an area of high annual rainfall. The Euphrates runs south through the Taurus foothills before flowing out into the steppes of northern Syria. It then turns to the southeast, where it receives water from the Balikh and Khabur River tributaries. The Tigris flows east, with the Taurus on its left bank and the low Tur Abdin mountains on its right. Unlike the Euphrates, it collects water from a number of left bank tributaries, most significantly the Batman, Garzan, and Bohtan Rivers in Turkey and the Upper and Lower Zab Rivers in Iraq. Both Euphrates and Tigris ultimately flow into the southern Mesopotamian plains near Baghdad. At that point, the low gradient of the southern plains causes the rivers to lose energy and to drop their suspended silt content. As a result, the Euphrates flows above the level of the plain on broad levees, which greatly simplifies the process of irrigation, the economic backbone of the urban civilizations of Sumer and Akkad (Wilkinson 2003, pp. 74-99).

In northern Mesopotamia, however, a different situation pertains, with considerable significance for settlement. The higher gradient of the Euphrates has led to a pattern of downcutting, and the rivers flow within narrow floodplains. On either side, the rivers cut through terraces from earlier aggradational phases, and it is on these elevated areas that most 
premodern archaeological sites are to be found. Within the floodplains, the rivers move dynamically, so much if not all floodplain settlement has been either covered over by alluvium or removed entirely. Because the rivers flow in floodplains beneath the level of the terraces, the opportunities for irrigation were few in the Bronze Age Tigris and Euphrates valleys. In the northern reaches of the Euphrates in Turkey and up to the area of the Syrian border, annual rainfall is high and reliable enough to support dry farming (greater than $300 \mathrm{~mm} / \mathrm{year}$ in most years) but broad areas of cultivable soils are infrequent outside of the narrow river valleys; further south in Syria, the valley is surrounded by extensive steppes but rainfall is too low for dry farming. The situation along the Tigris River is similar. As a result, the greatest developments in urbanization have taken place outside of the river valleys, although urban places were not unknown.

These riverine zones have been the targets of the most archaeological research in the last three decades, largely inspired by the construction of massive hydroelectric dams. Most are in Turkey, part of the Southeastern Anatolia Project (GAP), and include two recently completed dams on the Euphrates at Carchemish and Birecik and planned dams on the Tigris at Cizre and Ilisu. The Syrians and Iraqis downstream have followed suit. The initial dam on the Syrian Euphrates near al-Raqqa (the Tabqa Dam) was recently followed by a smaller dam upstream (the Tishrin Dam). In Iraq, the Tigris was dammed just above the town of Eski Mosul. All of these development projects were accompanied by a flurry of archaeological projects, many of which are now reaching advanced stages of publication.

The centers of social complexity and population nucleation, however, are mostly to be found away from the major rivers in a series of alluvial plains and basins along the northern arc of the Fertile Crescent. The most significant for this review is the Upper Khabur basin in 
northeastern Syria, a broad plain along the upper reaches of the Khabur River, and the adjacent plains north and south of the Jebel Sinjar in northern Iraq. To the west, the Urfa plain near the headwaters of the Balikh River supported substantial settlement. At least one major urban center is to be found in the Sajur basin just west of the Euphrates, and the plain north of the Jabbul Lake sustained a large population. It is probable that when archaeological research returns to Iraq, the plains along the left bank of the Tigris will also be found to have been highly developed in the 4th and 3rd millennia BC.

These areas have in common extensive stretches of deep soils with high agricultural potential and generally reliable rainfall. Given the absence of irrigation technology during the time frame discussed here, it is particularly interesting that some of the largest settlements emerged close to the limits of rainfed agriculture. The better-watered areas further north in the Zagros were characterized by smaller settlements, as were the drier areas in the steppe between the rivers and beyond the Euphrates to the south. The urban settlements in these alluvial plains have almost all been excavated to some extent, and in some cases for several decades. These areas are not threatened by inundation, so excavations have not proceeded with the sense of urgency found at sites in the proposed dam reservoirs; however, today these regions are all intensively cultivated, some via irrigation water from the dams, and many sites have suffered as a result.

Between the major river valleys, and beyond the edges of the alluvial basins, are extensive tracts of dry steppe that have in the recent past, and probably in antiquity as well, been the province of mobile pastoralists. These groups disappeared into them in the winter rainy season but returned to the rivers and well watered plains in the summers and during droughts, sometimes to the discomfort of sedentary communities. The steppes generally receive low 
amounts of rainfall (less than $200 \mathrm{~mm} / \mathrm{year}$ ) and cannot support reliable dry farming systems. The marginality of the steppe increases as one moves further to the south. The interface between the broad cultivated zones and the agriculturally marginal steppes were not fixed, however. In certain periods, settlement began to creep out into these areas, for reasons that are debated. A more favorable climate in the past is one possibility, but the coincidence of the spread of settlement with the appearance of urban states and empires suggests that social motivations combined with hydrological technologies may be behind such expansions.

\section{Chronology}

As a largely culture historical endeavor for much of its existence, Mesopotamian archaeology has placed great emphasis on chronology, often for its own sake, but the resolution of developmental issues targeted by more recent processual approaches also require an ability to subdivide time. The creation of artifact chronologies is not the most glamorous aspect of archaeology, but the past decade has seen consensus emerge on chronological terminology for the periods discussed in this paper, with new northern Mesopotamian sequences replacing older ones based on distant parallels, most often with southern Mesopotamia. Not all archaeologists have adopted these new chronological schemes, but in order to minimize confusion for a broad audience, I employ them in this review; therefore it is necessary to review briefly these recent chronological developments (Table I).

The city of Uruk in southern Mesopotamia is widely considered to be the world's first city (e.g., Liverani 2006), and its name has also been applied to the time of its emergence (roughly the 4th millennium BC) and the associated material culture; by extension "Uruk" is often used as an ethnic designation by archaeologists. This situation is confusing enough in southern Mesopotamia but even more so when these terms are used to denote periods and 
material culture in northern Mesopotamia, which has become common owing to the appearance of clearly southern Mesopotamian-derived or inspired materials in the north during this time (discussed below). Other archaeologists have adopted the Levantine-derived "Late Chalcolithic" term to describe 4th millennium northern Mesopotamia. Several new schemes were developed based on reassessments of earlier excavations at key sites and new excavated sequences (Gut 2002; Tomita 1998).

The most useful sequence emerged from a School of American Research Advanced Seminar held in Santa Fe in March 1998 (Rothman 2001c). The late 5th through 4th millennia were divided into five subphases (Rothman 2001a, pp. 5-8; Schwartz 2001) and tied to radiocarbon determinations (see also Hole 2001; Wright and Rupley 2001). The applicability of this new sequence is complicated by the intrusion of ceramics of southern Mesopotamian origin or inspiration in the final two phases. The first three periods (LC1-LC3) are defined entirely by indigenous developments in ceramic form and manufacturing techniques, whereas the key ceramic indicators for the final two period (LC4-LC5) are southern types.

In effect, the Santa Fe chronology combines two apparently independent ceramic sequences (the predominantly chaff-tempered indigenous sequence and the grit-tempered intrusive sequence) whose points of overlap are still debated. At Tell Brak, for example, the stratigraphic sequence for Area TW (Oates 2002; Oates and Oates 2002) spans the LC2 through LC5 periods. LC2 and LC3 levels are characterized by indigenous chaff-tempered ceramics. The LC4 level produced southern grit-tempered forms (the hallmark of the LC4 phase) but also indigenous chaff-tempered pottery that would otherwise be classed as LC3. The subsequent LC5 levels contain only grit-tempered sherds, which raises the question of whether the local chafftempered tradition had been abandoned completely or that such pots were simply not used in this 
relatively restricted part of a much larger settlement. This uncertain overlap of parallel ceramic traditions has repercussions for the interpretation of non-stratified surface materials, and settlement patterns in general; a site with a purely local surface assemblage might have been settled prior to the arrival of southern colonists and/or their ceramics (i.e., LC3), or it might have been contemporary but outside of the sphere of interaction (i.e., LC4). What is needed is a greater understanding of the evolution of the chaff-tempered tradition between LC3 and LC4; such distinctions are now starting to appear (Felli 2003; Pearce 2000).

The chronology of the 3rd millennium BC has witnessed a similar convergence of opinion. Previously, northern Mesopotamian stratigraphy was tied to distant sequences in the Levant or the southern Mesopotamian Early Dynastic I-III sequence (itself deeply flawed; see Evans 2007; McMahon 2006, pp. 145-146), or to site-specific chronological schemes. Building on a proposal by Peter Pfälzner (1997; 1998), a workshop was convened at the site of Tell Beydar in northeastern Syria in May 1998; the resulting sequence (Lebeau 2000) subdivides the 3rd millennium BC into seven phases (EJ 0 through EJ V, with EJ IIIa and EJ IIIlb subdivisions).

The EJ sequence works best with excavated sequences where the frequency of types can be gauged, because most types span more than one phase (noted at Tell Brak and Tell Beydar; Oates 2001; Rova 2003); the few chronologically restricted types tend to be minor components of the assemblage. Therefore it is difficult to place surface assemblages into a single phase of sequence, although there have been attempts (Pfälzner et al. 2004). Ultimately the ceramics of the 3rd millennium $\mathrm{BC}$ show substantial continuity, particularly for the middle to late part of the millennium, despite the great political and environmental upheavals that have been proposed. 


\section{Origins of complexity and urbanism, ca. 4400-3000 BC}

In the early to mid 5th millennium BC (the "Northern Ubaid" period), northern Mesopotamian society was characterized by largely egalitarian and communally oriented small communities without centralized leadership and little evidence for status marking, although possible architectural differentiation had emerged toward the end of the period at Tepe Gawra (Akkermans and Schwartz 2003, pp. 178-180). At this time, many aspects of material culture were widely shared across all of Mesopotamia, particularly a tripartite house form (Oates and Oates 2006) and a style of painted ceramics. Occasionally, it is possible to argue for an actual process of migration or colonization from southern Mesopotamia (Thuesen 2000), but in most cases we should envision the expansion of Ubaid culture as the peaceful spread of an ideological system (Stein and Özbal 2007).

Until the last decade, it was assumed that this situation continued into the 4th millennium until southern Mesopotamians, hailing from a more complex urban culture, arrived with new elements of social, economic, and religious complexity. The recent research reviewed here demonstrates that northern Mesopotamian society had in fact developed most if not all of the cultural hallmarks of Uruk society prior to that event. For the earliest phases (LC1-2), these include monumental architecture, organized long distance trade, specialized craft production, and new forms of population agglomeration; for the later phases (LC3-4), evidence exists for large scale feasting, religious institutions, mass production of ceramics, organized violence, and nucleated high density settlement (i.e., urbanism). These new data have substantial implications for the reconstruction of social development not only in northern Mesopotamia but also in the broader Near East. 
Status, specialization, and "proto-urbanism" in LC1-2

Until recently, the best evidence for this initial LC phase came from the small (ca. $1.5 \mathrm{ha}$ ) center of Tepe Gawra, located on the plain east of the Tigris near Mosul, Iraq. It was initially excavated in the 1920's and 1930's but has recently been restudied, with particular emphases on the changing nature of architecture and administrative practice through time (Rothman 2001b; 2002a; 2002b; Rothman and Peasnall 1999). A wide distribution of clay sealings in association with several extended family household compounds characterized the site in LC1; by LC2 specialized temple institutions had emerged and sealing activities became concentrated. This patterning is interpreted as the emergence of specialized leadership and control of resources centered around a new public institution (Rothman 2001b, pp. 387-389).

New evidence for monumental architecture appeared in the LC2 period in particular. At Tell Hammam et-Turkman on the Balikh River, a fragment of an elaborately niched and buttressed structure with walls almost $2 \mathrm{~m}$ thick was recovered on the mound's edge; unfortunately most of the structure was lost to erosion (Van Loon 1988). In contemporary levels at Tell Brak, excavations recovered the northwestern corner of a building with walls of similar thickness and with an enormous basalt stone door threshold (McMahon and Oates 2007, pp. 148155; Oates et al. 2007, pp. 588-590).

Adjacent to this monumental building at Brak was a structure with abundant evidence for manufacturing of various craft items. The structure itself contained multiple plastered basins and bins, and its floors featured pounders and grinding stones, stone and bone tools, spindle whorls, mother-of-pearl inlays, and extensive evidence for flintknapping (Oates et al. 2007, pp. 590591). Above this structure, a later LC2 structure also had industrial elements, including two large ovens of uncertain function and again, large quantities of flint and obsidian from all stages 
of the manufacturing process (McMahon and Oates 2007, pp. 150-152). This later LC2 (or transitional to LC3) structure at Brak also contained a remarkable object for the marking of status: a $16 \mathrm{~cm}$ high chalice constructed of obsidian, marble, and bitumen (Oates et al. 2007, Fig. 8). The bearer of this vessel must have been an individual whose elevated status would have been well indicated through its public use.

The presence of obsidian in LC1-2 levels is of particular interest because of the light it sheds on larger spheres of economic activity in the late 5th millennium. The movement of obsidian in the Neolithic is a well studied phenomenon, and the central and eastern Anatolian sources have been identified and characterized (Cauvin et al. 1998). LC1-2 obsidian from Brak and the "Southern Extension" of Hamoukar (known locally as Khirbat al-Fakhar) suggests a pattern of raw material movement of surprising complexity (Khalidi n.d.; Khalidi et al. in press). Khirbat al-Fakhar produced huge quantities of obsidian in all stages of the manufacturing process, from cores to finished tools, and in quantities that suggest production above the level of household utility. Given the great quantities of cores and debitage, the residents of Khirbat alFakhar must have had direct access to the source in the Bingöl region of the eastern Taurus mountains, and it is likely that the site was a point of redistribution for tools throughout northern Mesopotamia (Khalidi et al. in press).

These northern connections have a parallel in ceramics, as revealed by recent excavations and reappraisal of earlier fieldwork in the Caucasus (Lyonnet 2007b). Ceramics of LC2 and LC3 style have been found on sites in eastern Anatolia (Marro 2007) and even the Kura River basin in Azerbaijan (Akhundov 2007). Bertille Lyonnet (2007a, pp. 15-17) considers exchange in metals as the driving force, but the new evidence from Brak and Khirbat al-Fakhar suggest that obsidian exchange was also important. This pattern of north-south movement finds recent parallels with 
transhumant pastoralists; it is possible that similar movements existed in the late 5 th to early 4 th millennia BC. A more localized exchange network can be documented for "sprig ware," vessels with a distinctive vegetal motif that are the most distinctive ceramic indicator of LC1. A likely manufacturing center was found from surface remains on the edge of the Tigris River in northern Iraq (Ball 1997), and chemical analysis has been used to identify centers of manufacture and distribution (Rothman and Blackman 2003).

These new indicators of social complexity appeared simultaneously with dramatic settlement expansion at Brak and Khirbat al-Fakhar, although not in the form known from later periods of northern Mesopotamian history. Both were extensive "proto-urban" settlements of low or variable density, with few other parallels elsewhere in the Near East. The earliest, Khirbat al-Fakhar, is a vast low or flat scatter of pottery and obsidian (Ur 2002a, p. 64; Ur in press-b; Wilkinson 2002, pp. 99-104). Most of the site is a patchwork of lighter anthropogenic soils and darker natural soils with little or no topographic expression. Based on CORONA satellite imagery analysis and systematic surface collections, the LC1-2 extent of the site is at least 300 ha.

A similarly dispersed pattern of settlement characterized Tell Brak in the LC2 period. The central mounded area is surrounded by a halo of low mounds and flat areas (Oates et al. 2007, p. 587). Intensive systematic surface collection in these outer areas (the "suburbs") recovered LC2 sherds in discrete clusters of 2 to 4 ha, at intervals of 200-400 m from the central mound and from each other (Oates et al. 2007, p. 597; Ur in press-a; Ur et al. 2007). The total area of LC2 settlement at Brak covered at least 55 ha. The scale of settlement at Brak and Khirbat al-Fakhar in the LC1-2 periods was radically in excess of any of its neighbors, which did not exceed 5 ha (Hole 2000a; Hole 2000b; Lupton 1996). 
Indigenous urbanism and conflict in LC3-4

The succeeding phases of the early to mid-4th millennium BC witnessed further social developments, still prior to the arrival of people and ideas from southern Mesopotamia. The most dramatic trend was the continued growth of the LC2 "proto-urban" settlement at Brak into a spatially extensive and demographically large urban center in LC3-4. Conservatively, the central mound and suburbs together encompassed 130 ha of dense settlement a few centuries or more prior to the Uruk expansion (Ur et al. 2007). Other large LC3-4 settlements may have existed elsewhere in northern Mesopotamia at this time, but intensive field methods have not been applied to the non-mounded areas around other possible centers. The exception is Tell alHawa in the Iraqi North Jazira, which may have been as large as 33-50 ha at this time (Ball et al. 1989, p. 32; Lupton 1996).

Elsewhere on the northern plains, a few substantial nucleated towns of around 15 ha emerged, for example at Hamoukar (Ur in press-b) and Leilan. Most settlements, however, remained small, but now appeared with increased frequency across the landscape. Small villages on the order of 2.5-5 ha abounded on the alluvial plains (Wilkinson and Tucker 1995, pp. 44-45). Settlement remained ephemeral, however, in the Euphrates (Algaze 1999; Algaze et al. 1994; Geyer and Monchambert 2003, pp. 243-246; Wilkinson 2004) and upper Tigris (Laneri et al. 2006; Parker et al. 2008) river valleys, and the following discussion pertains largely to the northern plains.

The urbanization process at Brak was accompanied by further developments within the settlement. Institutionalized religion appeared with the monumental tripartite Eye Temple, which contained hundreds of small stone figurines with oversized eyes. It was initially dated to the late 4th millennium by its excavator (Mallowan 1947), but subsequent improvements in 4th 
millennium chronology now place its appearance in the LC3-4 (Oates and Oates 2002). The temple was heavily ornamented and would have sat at one of the highest points in the city at the time (Emberling 2002). The terrace and ornamentation set the Eye Temple apart from domestic structures, which employed the same tripartite ground plan.

Evidence from such domestic areas also documents emerging complexity in smaller household contexts. Several LC3-4 structures were recovered from TW Levels 18-16. The Level 18 tripartite building is of particular interest. The open courtyard in front of the building contained a large domed oven and a grilled structure, in association with large amounts of animal bones and large thick-walled bowls or plates. The excavators interpret this assemblage as the product of supra-household feasting conducted by a local figure of authority, some sort of sheikh (Emberling and McDonald 2001, pp. 21-31). Other LC3-4 domestic structures show evidence for high value wealth items and exotic materials. The burnt remains of one house contained scraps of ivory, carnelian, and gold objects (Oates and Oates 1993, pp. 177-178). A cache from a pit included two stamp seals and 350 beads, mostly of carnelian but including silver, gold, lapis lazuli and rock crystal (Emberling and McDonald 2003:9). It is likely that exotic materials were more prevalent in elite LC3-4 households than current archaeological evidence suggests, but the almost complete absence of adult burials from the time deprives archaeology of access to such luxury items and materials that had been taken out of use context in the past.

Control of property is evident through the widespread use of clay sealings and stamp seals. After a vessel, bag, or box was closed, or a door locked, a piece of clay was placed over its knot or lock; the engraved side of a small stone or bone seal was then pressed into the wet clay, leaving an impression whose distinctive design served to designate the individual or institution under whose control the contents of the container or storeroom had been placed. 
Sealings were used in LC1-2 (e.g., Rothman 2002b), but nearly every excavated context of the LC3-4 period has produced impressed clay sealings, and occasionally the seals themselves. Within the domestic structures at Hamoukar, hundreds of sealings had been placed on jars and containers of perishable materials; some of these containers had been stored on the roof or a second story and had fallen into the room when the building was burned (Reichel 2002). The LC3-4 structures at Brak Area TW also had evidence for substantial sealing activity (in evidence already in the preceding LC2 levels), and many container sealings were discarded in the large midden on the northern edge of the site (Pittman in Emberling and McDonald 2003; McMahon and Oates 2007, pp. 163-166). Further west, seals and sealings also have been found in smaller sites on the Euphrates such as Hacinebi (Pittman 1999) and from a slightly later time, Arslantepe (Frangipane 2007a). The designs themselves often show a naturalistic style most often associated with later cylinder seals of southern Mesopotamian design. The seals are carved from bone or soft stone and have the overall shape of a kidney bean or a recumbent animal (Pittman in Emberling and McDonald 2003; Gibson et al. 2002b; Reichel 2002).

The widespread use of sealing technology in elite, domestic, and midden contexts and in cities and villages, suggests that concerns about property control were by no means limited to an elite subset of early 4th millennium society. Sealing in northern Mesopotamia existed since the Neolithic (Akkermans and Duistermaat 1997), and despite frequent equations of sealing practice with bureaucracy and the state (e.g., Frangipane 2007b), the emergent evidence from LC3-4 levels puts sealing as a property control mechanism at the level of the household. Larger households with more resources to control may have used the practice more frequently, but it was clearly not restricted to centralized political authority. 
An administrative technology conspicuous by its absence in northern Mesopotamia is writing. The development of a pictographic writing system, later to develop into the cunieform script, holds an important position in most discussions of the origins of urbanism in southern Mesopotamia (Algaze 2008, pp. 135-139; Liverani 2006). In any case, the appearance of writing in the south ca. 3200-3100 BC (Englund 1998, pp. 32-41) was a very late development, and may have post-dated the collapse of the Uruk Expansion (see below). Writing appears to have been an innovation of urban institutions in southern Mesopotamia that was later adopted in neighboring regions, but was not a critical one for urban origins in northern Mesopotamia.

The social and political changes in the LC3-4 periods were not without conflict. Structures at Hamoukar and Brak were destroyed by fire. The most striking evidence comes from recent excavations on the northern edge of Brak's outer town, where thick layers of LC3 debris contained the remains of at least 67 individuals in a partially articulated state (McMahon and Oates 2007, pp. 155-163). Human skulls occurred in discrete clusters, and there was an almost complete absence of hand and foot bones. Infants were completely absent; most identifiable remains came from older children and young adults. The fact that no other noninfant burials are known from elsewhere in Mesopotamia raises the possibility that these remains may represent the final phase in the standard mortuary practice at the time (Karsgaard and Soltysiak 2007, p. 158), but the excavators assume that the remains originate with a massacred local population that was subsequently brought to the edge of the settlement and thrown out with other debris (Sołtysiak 2007, p. 163). Atop the human remains were found the disarticulated but nearly complete remains of more than 30 sheep and as many as 10 cattle that, due to their completeness, consistency of butchering patterns, and lack of carnivore damage, are interpreted 
as the remains of feasting events held over the dead and then quickly covered over (Weber 2007, pp. 167-168).

The signs of violence at Brak and Hamoukar must be interpreted with caution. The destruction at Hamoukar is attributed to conquering southern Mesopotamians who subdued the town under a hail of clay sling balls before putting it to the torch; others see those artifacts as clay blanks for sealings (Lawler 2006, p. 1462; Oates et al. 2007, p. 593). The identity of the attackers also remains open to question; given the presence of medium to large settlements at Brak, Hamoukar, Leilan, and Tell al-Hawa, one might envision a pattern of peer polity competition within the region rather than foreign conquest. The possibility of intra-community conflict should not be excluded, either. At Tell Brak, the evidence for massacre is roughly contemporary with its unprecedented urban growth. As social hierarchies formed within its expanding population, competition for power may have resulted in bloodshed.

Colonization and emulation during the "Uruk expansion" in LC4-5

Our understanding of local northern Mesopotamian developmental trajectories are complicated by the influence of southern Mesopotamian culture, which started in the LC4 period and intensified in the LC5 period. This Uruk "Expansion" (Algaze 1993) or "Intrusion" (Akkermans and Schwartz 2003) was assumed to have been a single shortlived event at the end of the millennium, but recent fieldwork and radiocarbon dates have proven that it started earlier and lasted longer than was originally appreciated (Wright and Rupley 2001). Guillermo Algaze's The Uruk World System (1993) hypothesized that the widely scattered traces of southern Uruk styles of material culture, which sometimes occurred alongside indigenous artifacts and sometimes occurred at homogeneously Uruk sites, were the remains of an informal economic empire whose asymmetric trade relationships with local communities in northern 
Mesopotamia and elsewhere created growth-retarding economic dependency on long distance trade. The closure of the Uruk homeland in Iraq to fieldwork has spurred interest in the mid to late 4th millennium in recent years (Collins 2000; Postgate 2002; Rothman 2001c). Because much of this work has been reviewed recently (Akkermans and Schwartz 2003, pp. 181-210; Butterlin 2003; Rothman 2004; Schwartz 2001), I will limit myself here to a summary and very recent new findings.

Algaze's hypothesis was given its most rigorous test at Hacinebi, a 4 ha village site on a bluff overlooking the Euphrates River near Birecik, Turkey. A surface survey found artifacts of both local and southern Mesopotamian style, which hinted at the possibility of the replacement of an indigenous population by southern colonists, or cohabitation. Using seven seasons of excavation data, Gil Stein (1999) concluded that the Uruk colonists could have only been present with the agreement of the local community, which proved to be much more complex and technologically advanced than Algaze's model predicted. After critiquing the use of Wallerstein's world systems theory for the Uruk Expansion, and in premodern contexts in general, Stein proposes a "distance parity model" wherein the ability to project military force and economic domination decays with distance.

In the Euphrates River valley, the filling of the reservoirs behind the dams in Turkey and Syria means that many Uruk expansion sites are no longer accessible by archaeologists. Nonetheless, recent research at one site raises the possibility that the spatial extents of the colonies may have been underestimated. Tell Jerablus Tahtani is a small site whose Uruk component is mostly inaccessible beneath occupation of the 3rd millennium BC (Peltenburg 1999b). The mound itself is 1 ha, but recent intensive surface collection and geomorphological observations have revealed an additional 12 ha of lower settlement surrounding it, currently 
covered by Euphrates alluvium (Wilkinson et al. 2007c, pp. 228-229). The other major colonies on the Euphrates at Habuba Kabira (Vallet 1996) and Jebel Aruda (Vallet 1998; van Driel 2002) are also mostly unmounded. Traditional Near Eastern survey techniques are highly focused on mounded sites and would therefore be likely to miss such places (Wilkinson 2000a).

Social trajectories of the late 5th through 4th millennia in northern Mesopotamia

Most LC1-4 sites were small villages, presumably largely self-sufficient in terms of their staple economies. Tepe Gawra, the most extensively excavated, has been characterized as the center of a chiefdom (Forest 2001; Rothman 2002b, pp. 141-148). The new morphologies and patterns of settlement growth at Khirbat al-Fakhar and Tell Brak, however, raise some difficult questions, particularly in combination with new evidence for indigenous social complexity. Can we call these places urban? Should we speak of "states" in the late 5th and early 4th millennia? The unprecedented scale of Khirbat al-Fakhar (at 300 ha, larger than Uruk itself) at such an early date (LC1-2) has led some to question whether it was permanently occupied, and to propose that settlement may have moved around within it, rather than the entire settlement having been occupied at any given time (Gibson et al. 2002a; Wilkinson 2002). The density of surface ceramics, and the prevalence of large storage jar forms, argues against the site as a pastoral encampment and for at least a semi-sedentary component. It does seem improper, however, to assume a settlement density similar to the excavated cities of the Bronze Age. The distribution of surface artifacts and areas of anthropogenic soils on satellite imagery suggests a dispersed internal structure, with clusters of settlement and low density or vacant areas in between. Even if settlement density was low, Khirbat al-Fakhar was an important population center with obsidian exchange, manufacturing, and distribution functions found nowhere else. 
The spatial pattern at Brak is similar at a smaller scale. Brak's 55 ha comprised a central mound, apparently nucleated, with smaller discrete outlying settlement clusters. It has been proposed that the spatial autonomy of the outlying clusters reflected an underlying desire to maintain sociopolitical autonomy. Unrelated communities felt some sort of centripedal pressures (for reasons economic, religious, or both) but in the absence of social institutions to integrate them (Ur et al. 2007). Such institutions must have developed during the course of the LC3-4, as Brak expanded to 130 ha.

Whether these places can be assigned urban status depends on one's definition of urbanism. Brak's urban significance has been downplayed because, unlike the cities of southern Mesopotamia, it was a primate center without intermediate centers in a proper urban hierarchy (Algaze 2008, pp. 118-120). Whether this is the case remains to be seen (a survey of the Brak hinterland has recently been completed by Henry Wright), but it does apply a potentially anachronistic modern Western spatial model to the 4th millennium BC. Instead of arguing against Brak's urban significance on the basis of this single factor (settlement pattern hierarchy), it is preferable to view these sites and their urban properties through "axes of variation" as proposed by George Cowgill (2004). By the middle of the 4th millennium (LC3-4), most of the variables that one can imagine were skewed toward urban status for Tell Brak, a spatially large and densely populated settlement with indicators of centralized economic, religious, and political functions (Oates 2005, pp. 14-28). Its earlier LC2 incarnation, and also LC1-2 Khirbat alFakhar, appear have lower population density and perhaps lacked internal political centralization and economic specialization; for these reasons, these places might be called "proto-urban." It seems possible that spatially extensive, low-density antecedents existed for other early cities but 
have not been recognized due to alluviation, subsequent settlement, or choices in archaeological field methodologies.

Few archaeologists hesitate to ascribe to the city of Uruk at the end of the 4th millennium BC the status of "state," but can the case be made for northern Mesopotamian states in the late 5th and 4th millennia BC? The excavators of LC5 Arslantepe interpret the elaborate system of property control via sealing as evidence for a centralized bureaucracy that redistributed rations to dependents (Frangipane 2007b). At Gawra and elsewhere (Rothman 2004), the evidence of the sealings has been described using the terminology of the state (for example, "officials" in a "bureaucratic" system). Neo-evolutionary terminology has been strongly critiqued in recent years, but while the utility of the chiefdom model may be questioned, even the strongest critiques still employ the state concept (e.g., Yoffee 2005, p. 54). This term, as applied in archaeological contexts, comes with a range of associations that seem inapplicable to these cases: a rationalized bureaucracy, specialized governing institutions, and above all, the reduction or elimination of kinship as a political organizing principle.

On the other hand, the wide distribution of clay sealing technology seems to indicate decentralized economic control. When "administrative" or elite structures can be identified, they all share a common tripartite plan. Rather than a discrete state apparatus, it seems more likely that these cities and polities were ruled by powerful households, of varying scales, some of which were secular (for instance, the TW Level 18 feasting hall at Tell Brak discussed above) and others envisioned as the household of the gods (e.g., the Eye Temple). The ground plans of these structures differed from domestic structures only in scale and ornamentation; it is certain that anyone entering the Eye Temple would have understood its tripartite plan to represent a house. The house as a metaphor for larger political entities was common throughout the Bronze 
Age Near East (Schloen 2001) and is being used in models for the later 3rd millennium as well (discussed below).

These new findings demonstrate the indigenous nature of urbanism at Tell Brak, which appeared well in advance of any presently identifiable influence from Uruk or its southern Mesopotamian neighbors; the emergence of the Mesopotamian city must therefore be considered a multicentric phenomenon, if not a process that occurred independently in multiple loci. Indeed, the possibility is now raised that northern urbanism predates its appearance in the south. The advances in LC chronology have allowed us to document the spatial development of Brak with much finer chronological precision than is possible for Uruk. The monumental structures and pictographic tablets from Uruk come from the very end of the 4th millennium (LC5) and may post-date the collapse of the Uruk Expansion (Englund 1998, pp. 34-35; Schwartz 2001, p. 242). Because of the architectural focus of the early excavators, the Uruk ceramic chronology is poorly known (Nissen 2002); the city's extent was 250 ha in LC5 (Finkbeiner 1991) but because of these chronological problems, it is unclear if it was so large earlier in the 4th millennium.

A final point on the comparative developmental trajectories for northern and southern Mesopotamia concerns the role of the environment. Algaze has argued forcefully that the nature of the southern alluvial landscape gave it a substantial advantage in the development and maintenance of urban society $(2001 ; 2008)$. In the south, the landscape enabled irrigation technology, which raises crop yields, reduces the risk inherent in annual climatic fluctuations, and provides a low friction means of transporting bulk items, including harvested cereals (Wilkinson 2003, pp. 74-99). With this staple economic framework, cities emerged through a non-linear process of peer polity competition (Algaze 2008). Dry farming is highly susceptible to fluctuations in rainfall, and as a result, urbanism in northern Mesopotamia was more limited in 
scale and dangerously susceptible to collapse when cities pressed up against a ceiling of around 100 ha, given certain assumptions of transportation and agricultural technology and cereal productivity (Wilkinson 1994). The new evidence from northern Mesopotamia shows that large nucleated settlements could emerge in this supposedly disadvantageous landscape. Environment was certainly a constraining factor and cannot be ignored when considering why cities were so much more durable and prevalent on the southern plains.

The critical elements, however, that enabled the formation of these large settlements were the social institutions that brought communities together and maintained their cohesion. The nature of such institutions can only be speculated upon at present, given how much of our data comes from surface survey. The small glimpse from Brak TW level 19 suggests the emergence of a predominantly secular institution that marked its elite members through exotic drinking vessels and was engaged in the production (and probably distribution) of items made from imported materials (i.e., a wealth-based political economy).

\section{Deurbanization and regionalization, ca. 3000-2600 BC}

After the clear signs of social complexity, both indigenous and southern Mesopotamian in inspiration, disappear at the end of the fourth millennium BC, northern Mesopotamia appears to have entered a period of "devolution" (Schwartz 1994a, p. 154) in the beginning of the third millennium BC, a time when society in southern Mesopotamia was reaching its urban apex. The Uruk colonies vanished, along with almost all traces of interaction with the south. The lower town at Brak was abandoned; the plains and river valleys alike were characterized by small tellbased villages (Wilkinson 2000a). The broad similarity of ceramic traditions across northern Mesopotamia in the 4th millennium gave way to regionalized assemblages, probably indicative of a reduction in interregional interaction. 
The Ninevite 5 period (EJ I-II) in the Upper Khabur basin and northern Iraq

The early 3rd millennium in this region has traditionally been labeled the "Ninevite 5" period, after the distinctive painted and incised pottery tradition known from the fifth level of the deep sounding at Nineveh (Gut 1995, pp. 9-19). The earliest variety was decorated with a redbrown to purple paint, mostly in geometric designs; this style then appeared beside a fine incised variety. An elaborate excised style was introduced later, followed by a somewhat careless zigzag style at the end of the period (Calderone and Weiss 2003, pp. 198-199; Rova 1996; 2000). A post-LC5, pre-EJ I ceramic tradition, now labelled "EJ 0," is known only from Tell Brak (Oates and Oates 1991).

Early 3rd millennium settlement remains obscure, largely because EJ I-II levels are sealed beneath substantial later occupational debris. The construction of monumental buildings damaged or removed EJ I-II layers in antiquity, as earlier buildings were leveled and preexisting tell surfaces were terraced. Settlement surveys have also run into difficulties. The decorated EJ I-II types, which are the most chronologically sensitive, are not robust and occur infrequently in surface assemblages.

For these reasons, we know comparatively little about the early 3rd millennium at the places that grew to urban proportions later in the millennium. We do, however, have remarkable knowledge from areas where salvage projects rescued sites in advance of dam reservoir construction, particularly the Khabur River dam below Hassake in Syria (Martin 1998; Monchambert 1984), the Eski Mosul dam on the Iraqi Tigris, above Mosul (Ball and Wilkinson 2003), and the Tabqa, Tishrin, and Carchemish dams on the Euphrates (Cooper 2006; Peltenburg 2007b; Wilkinson 2004). The picture of EJ I-II settlement emerging from the Middle Khabur area, where many of the twenty-two 3rd millennium sites were excavated, is particularly vivid. 
Bearing in mind these data shortcomings, some tentative generalizations can be made about north Mesopotamian societies at the time. The EJ I-II countryside consisted of dispersed small settlements, with a few small towns of 15-25 ha (Matthews 2003a, p. 133; Stein and Wattenmaker 2003; Wilkinson and Tucker 1995, pp. 49-50). Excavations suggest a reduction in social complexity in the EJ I-II period (Akkermans and Schwartz 2003, pp. 216-224). The use of tokens and sealed bullae as administrative technology disappeared after the collapse of the LC 45 Uruk expansion. There are no examples of writing known from EJ I-II sites, but the use of cylinder seals continued. Mass production of pottery, which was done on a large scale in the mid- to late-fourth millennium (e.g., Oates and Oates 1993, pp. 181-182), all but disappeared with the end of the Uruk period. In its place appeared new labor-intensive production methods that involved extensive surface decoration. A degree of social stratification is apparent in burial assemblages, but in general there is little evidence for economic specialization or powerful political institutions (Akkermans and Schwartz 2003, pp. 223-224).

Religious institutions have, however, been identified. Unlike the multiroom and elaborately decorated tripartite structures of the LC3-5, these were small single-room structures, often with interior benches and a small podium, placed in the midst of a courtyard (Matthews 2002). When a broader context is known, they are found within the settlement fabric, as at Tell al-Raqa'i (Schwartz 2000). EJ I-II temples in northern Mesopotamia provide a stark contrast to southern Mesopotamia, where such institutions were large economic households. Nonetheless, the cache of over 500 sealings from the small temple at Tell Brak demonstrates a concern with property control (Matthews 2003a, pp. 111-113).

Residential buildings, when they have been fully excavated, were small one- or two-room structures with little ornamentation or size differences between them (Schwartz and Klucas 
1998). Monumentality is by no means unknown; at Raqa'i and Tell Khazna, large round buildings have been excavated. The structure or structures at Khazna are enigmatic (Munchaev and Merpert 2002, pp. 245-257). The Raqa'i round building was $20 \mathrm{~m}$ in diameter and contained vaulted storage rooms, brick platforms, and industrial scale ovens (Schwartz and Curvers 1992).

From this dataset, several scholars have labeled these societies as chiefdoms (e.g., Akkermans and Schwartz 2003, p. 224; Matthews 2003a; Schwartz 1994a). However, there is some evidence from the middle Khabur region that economic organization was more complex than mere household agricultural self-sufficiency. The excavators of Tell al-Raqa'i proposed that it and other small villages on the middle Khabur were not simple agricultural villages but rather specialized centers for storage, processing, and distribution of grain products, tied into a regional economic system (Akkermans and Schwartz 2003, pp. 218-222; Fortin 2000; Schwartz 1994b). They contend that the recovered storage facilities at Raqa'i and elsewhere at this time greatly exceeded the needs of the estimated ancient populations, and were probably used for storing grain staples that were to be shipped via river transport to larger polities elsewhere, perhaps upstream to Tell Brak or downstream to Mari on the Euphrates (see also Margueron 2004, pp. 120-121).

This rural specialization model has been critiqued from two directions, both proposing local consumption. Frank Hole's survey in the West Jazira area around the Jebel Abd al-Aziz recovered as many as 36 sites of the first half of the third millennium BC (Hole 1991; 1997; 1999). By using a lower population estimate, Hole suggests that the surplus was for both local consumption and fodder for livestock. In the wet season, flocks would have grazed on the steppe beyond the river floodplain; in the dry season, these flocks, and their human shepherds, would have needed to return to the floodplain for water and food. Furthermore, the wetter conditions in 
the first half of the third millennium $\mathrm{BC}$ would have meant that the land would have also been more productive (Hole 1999). This interpretation is complemented by zooarchaeological data suggestive of a specialized animal economy focused on sheep and goat production (Zeder 1998; 2003, pp. 170-175). Another reassessment by Peter Pfälzner (2002), in combination with comparisons of domestic storage throughout northern Mesopotamia, also proposes local consumption, but by the human population of the village.

Much of the differences between these models revolves around the quantity of surplus agricultural production, which in turn derives from equally plausible reconstructions of ancient population density and total volume of storage space. However, it is worth emphasizing some of their underlying assumptions. The surplus-shipping model assumes that surplus production will be externally motivated, in this case under the impetus of an extractive centralized polity, and is strongly influenced by the hierarchical emphasis of ecosystems theory. Hole's pastoral interaction model, on the other hand, is more heterarchical in that it recognizes the possibility of non-sedentary groups which may have had fluctuating political and economic relationships with sedentary agriculturalists, and may have been socially interrelated (see also Danti 2000). Indeed, a dynamic relationship between the two groups may have been important in the formation of the large Kranzhügel settlements on the steppe in the later 3rd millennium BC (Kouchoukos 1998; Lyonnet 1998).

The early 3rd millennium in the Euphrates River valley

The archaeology of the Euphrates Valley in the 3rd millennium BC has advanced considerably in recent years as a result of recent edited volumes (del Olmo Lete and Montero Fenollós 1999; Peltenburg 2007a) and an excellent synthesis (Cooper 2006). It was a time of great changes in populations and interaction spheres in the Euphrates River valley. The southern 
Uruk presence disappeared, and new groups from the Caucasus filtered into the region. This phenomenon is particularly clear at Arslantepe, on the northern fringes of the Uruk expansion, which went from close cultural connections to the Uruk world to the burial place, and possible campsite, of mobile pastoralists of the Kura-Araxes or Early Transcaucasian Culture (Frangipane et al. 2001; Wright 2007).

The sites on the Turkish Tigris were small and replaced a combination of indigenous and southern Uruk villages (Algaze 1999, pp. 544-546), and also on the Syrian Euphrates, where they filled in a near vacuum of settlement (Cooper 2006, pp. 47-68; Wilkinson 2004, pp. 136-138). As is the case with the Middle Khabur region discussed above, it would be a mistake to assume that they were homogeneous subsistence-oriented villages; excavations have revealed a remarkable degree of specialized features. For example, the small site of Hajji Ibrahim, near Tell es-Sweyhat, had specialized grain storage functions, perhaps in the context of a complex agropastoral economic system (Danti 2000; Danti and Zettler 2007). Monumental architecture was a common feature; many small sites were heavily fortified (Cooper 2006, pp. 71-73), and one site, Gre Virike on the Turkish Tigris, appears to have been composed entirely of a monumental brick platform, serving some sort of regional cultic function (Ökse 2007). Within settlements, the structures identified as religious in orientation are small and single roomed (Cooper 2006, pp. 143-150).

\section{Resurgence of urbanism and complexity, ca. 2600-2000 BC}

At the end of the EJ II period, a handful of villages in Northern Mesopotamia underwent a rapid process of urbanization (Akkermans and Schwartz 2003; Stein 2004; Wilkinson 1994). The rapid appearance of new social institutions and forms of economic and political organization can be detected in several ways: labor mobilization to construct massive city walls, terraces, 
palaces and temples; increased specialization in the production of pottery, metals and other crafts as well as administrative and religious tasks; and intensification of agricultural and pastoral production. These new (or newly enlarged) institutions were located in urban places. Although cities reappeared in later periods, this was the most pervasive phase of urban settlement prior to the 20th century AD. The EJ III period brings northern Mesopotamia into the light of history, with the earliest cuneiform tablets found at Ebla, Tell Beydar, and Tell Brak (Archi and Biga 2003; Eidem et al. 2001; Ismail et al. 1996).

Settlement, landscape, and subsistence

The most obvious manifestation of this process is the expansion of settled areas at the major sites. The greatest urbanization occurred in the well watered alluvial plains of the Upper Khabur Basin and adjacent areas of northern Iraq. Tell Leilan, Tell Mozan, and Hamoukar all grew from around 15 ha to 90-120 ha within a century (Pfälzner et al. 2004; Ur 2002b; Weiss and Courty 1993, pp. 135-136). Tell Brak expanded to 65-70 ha (Emberling et al. 1999, p. 16; Ur in press-a). In Iraq, major cities emerged at Tell al-Hawa, Tell Taya, and Tell Khoshi (Ball et al. 1989; Kepinski-Lecomte 2001; Reade 1997). A range of intermediate towns, such as Titriş Höyük and Tell Beydar, attained 25-45 ha (Lebeau 1997; Matney and Algaze 1995). In the Euphrates river and adjacent areas of western Syria, the largest urban sites at Ebla, Tell Hadidi, Tell Sweyhat, Tell Banat, and Tilbeşar appear have have had a lower growth ceiling and did not exceed 50-65 ha (Cooper 2006, pp. 49-58; Kepinski 2007; Wilkinson 2004, pp. 233-234; Zettler 1997). At this time of maximum urbanization, towns even extended out to the margins of the steppe, for example at Tell al-Rawda (Castel and Peltenburg 2007) and the distinctive circular walled Kranzhügel sites in the steppe between the Khabur and Balikh Rivers (Akkermans and Schwartz 2003, pp. 256-259). 
EJ III-IV cities all developed out of earlier settlements, some of which had been occupied for millennia. In most cases a lower and extensive area of settlement formed around the older mounded core. The monumental buildings on the upper mounds have received the most archaeological attention. When excavated, lower areas have proven to be areas of dense domestic houses along narrow streets and alleys (Colantoni 2005; Pfälzner 2001; Senior 1998). In the rare case of Tell Taya, the stone foundations of the entire settlement could be mapped on the surface (Pfälzner 2001, pp. 321-325; Reade 1997). More recently, geophysical surveys have demonstrated the radial nature of many of these cities, with wide streets radiating outward from the central core toward gates in the outer city wall (Creekmore 2008; Gondet and Castel 2004; see also Matney and Algaze 1995; Meyer 2006; Meyer 2007; Pfälzner et al. 2004).

Where regional settlement patterns have been recovered, the relatively undifferentiated EJ I-II pattern gave way to a hierarchical distribution of cities, towns and villages. Settlements' estimated sustaining areas overlapped substantially, and the larger centers would have required import of surplus agricultural products (Stein and Wattenmaker 2003). The plains of the Iraqi North Jazira supported a three-tiered hierarchy of settlement size, with 66 ha Tell al-Hawa at the apex (Wilkinson 1994, pp. 487-490; Wilkinson and Tucker 1995, pp. 50-53).

The growth of urban centers put pressure on their hinterlands to cover their productive deficits, resulting in a lasting impact on the landscape. Farmers, herders and their animals moved across the extensively cultivated plain on local and intersite tracks that are visible in aerial and satellite photographs, and occasionally on the ground (Altaweel 2004; Ur 2003; Wilkinson 1993; Wilkinson 2003, pp. 111-117). Over 6,000 km of tracks could be mapped in the upper Khabur basin via CORONA satellite photographs (Ur in press-b Chapter 7), but such features are preserved more sporadically in western Syria (Wilkinson 2004, pp. 81-82). An 
alternative interpretation as channels for water harvesting (McClellan et al. 2000) is problematic because many tracks move over the terrain in ways that would be hydrologically impossible (Ur and Wilkinson 2008, pp. 311-312). Formation of these depressed tracks was related to the duration and intensity of use but also the degree to which movement was constrained onto them by the presence of agricultural fields; by extension, they serve as a proxy indicator of the limits and intensity of cultivation and possibly the violation of fallowing (Ur 2009; Wilkinson 1994, pp. 492-493).

Further evidence for agricultural intensification comes from the continuous spread of small and abraded potsherds at low but variable density. Such scatters are particularly dense in the zone of greatest urbanization in the upper Khabur basin and the plains of northern Iraq. They are interpreted as the remains of ancient manuring practices where settlement-derived debris was deliberately deposited on the fields as a crop amendment (Wilkinson 1994, pp. 491-492; Wilkinson 2003, pp. 117-118). The greatest densities are associated with EJ III-V urban centers, for example around Hamoukar, Tell al-Hawa, and Tell Sweyhat (Ur 2002a, pp. 76-80; Wilkinson 2004, pp. 57-73; Wilkinson and Tucker 1995, pp. 19-23). This interpretation is not universally accepted (see especially the comments to Wilkinson 1994), but no alternatives have been proposed that can explain the ubiquity of the scatters. In combination, the landscape data from linear trackways and manuring scatters is strong proxy evidence for an intensive agricultural economy.

This agricultural economy largely revolved around the production of cereals, particularly wheat and barley, but in most cases, barley predominates in the botanical assemblages. At Tell Brak, the presence of cereal byproducts shows that animals were grazing on the stubble of harvested fields or being foddered, and indeed it is possible that the intensive cultivation of 
barley may have been for animal, rather than human, consumption (Charles and Bogaard 2001; Hald and Charles 2008). The zooarchaeological record shows a dramatic reduction in wild species and a very strong emphasis on sheep and goat just prior to and during the EJ III-V urbanism phase (Zeder 1998; Zeder 2003). Within settlements, pigs were kept at Brak (Weber 2001) and Leilan in both elite and household contexts (Zeder 2003, pp. 175-176).

To understand how the massive population concentrations at 3rd millennium cities were able to sustain themselves, T.J. Wilkinson and colleagues have developed an evolving set of models that use these settlement, landscape, and agropastoral variables as inputs, along with data from traditional Near Eastern agriculture and the cuneiform record (Christiansen and Altaweel 2006; Wilkinson 1994; 1997; 2000b; Wilkinson et al. 2007a; 2007b). Wilkinson's "first principles" approach (1994, p. 484) prioritizes the productive potential of the land surrounding early urban settlements, based on human biological needs and principles of least effort. The model considers the dynamic interaction between environment (soils and the amount of and variation in rainfall), settlement, and land use strategies. Early iterations focused on the relationships between population and land use alternatives at a single settlement (Wilkinson 1997), and between labor, land use, and carrying capacity in a multiple-settlement urban system (Wilkinson 1994). In both, variation in rainfall (and by extension, predictability of crop yields) and labor availability were the major limiting factors. At a threshold of 2,620 persons, a settlement's entire catchment would be under cultivation, and any additional population would begin to consume surplus production. At 6,000-8,000 persons, the settlement would require surplus to be imported from neighboring settlements, the optimum arrangement of which was a pattern of six satellites with five-kilometer territories around the five-kilometer territory of the urban center. Wilkinson's model predicts a maximum population of 11,734-14,374 persons in 
centers (a size of 72-114 ha, depending on density), which closely approximates the 100-120 ha ceiling for the sizes of the largest EJ III-V sites (Wilkinson 1994, pp. 501-502). As settlements approached this ceiling, however, the economic system became increasingly susceptible to fluctuations in annual rainfall and could collapse if faced with a multi-year drought.

The impact of Akkadian imperialism in northern Mesopotamia

Political events represent a complicating factor in the development of urban polities. Royal inscriptions of two kings of the Akkadian dynasty of southern Mesopotamia, Sargon and Naram-Sin, describe military campaigns in northern Mesopotamia and the capture and destruction of cities (Westenholz 1999). Many archaeologists assume that the EJ IV phase, defined ceramically, is largely coterminous with a period of Akkadian imperial control (e.g., Lebeau 2000 Table IX). The nature and impact of these events are debated, however. For some, the Akkadian conquest was a watershed event with broad repercussions (Weiss and Courty 1993); for other models, it plays no role whatsoever (e.g., Wilkinson 1994).

The evidence for Akkadian conquest and political control must be considered critically. Epigraphic data comes almost exclusively from royal inscriptions, which are by nature propagandistic devices and prone to hyperbole; furthermore, they describe conquest but say nothing of control or administration. The sparse cuneiform material from Tell Brak and Tell Leilan (de Lillis Forrest et al. 2007; Eidem et al. 2001) is written in a script identical to that of Akkadian administrative documents in the south, but the texts themselves make no mention of the Akkadian state (Eidem et al. 2001, p. 102). A few sealings bear the impressions of seals of royal servants, but these may have arrived on containers from elsewhere and could therefore bear witness to elite exchanges between independent polities (reviewed below). Likewise, the presence of a daughter of Naram-Sin at Tell Mozan (Buccellati and Kelly-Buccellati 2002) fits 
into a larger pattern of diplomatic marriages (e.g., Biga 1998) and need not indicate political subservience.

The only indisputable physical manifestation of Akkadian imperial control remains the massive "Naram-Sin Palace" at Tell Brak, the mud bricks of which were stamped with the name of that king (Mallowan 1947, pp. 63-70). Akkadian imperialization cannot otherwise be detected in architecture or any other aspect of material culture, which evolved independently from the forms and styles of Akkadian southern Mesopotamia (Oates and Oates 2001a, p. 383). Certainly there was direct Akkadian administration of Tell Brak but whether it lasted a year, a decade, or for Naram-Sin's entire reign, or if it extended beyond Tell Brak, is entirely unknown. The great volume of recent work on the later 3rd millennium in northern Mesopotamia has not negated Michalowski's statement that

We indeed put too much emphasis on the raids which Sargon and Naram-Sin effected in the north and north-west of Mesopotamia. In fact it is a great credit to the ancient propagandists of the Sargonic [Akkadian] kings, and their later successors, how well modern scholarship has been affected by the fruits of their labors. Infected with these examples, archaeologists who excavate in Syria have not wanted to be left behind and have invented non-existent empires which are modeled after the propagandistic vision of Mesopotamian statesmen, as filtered through modern eyes... [The data suggests] a historical and political development largely independent of their cultural and linguistic cousins in Sumer and Akkad, the presence of Naram-Sin's garrison at Tell Brak and possibly in a few other towns in the region, a few victory cartoons, and scribal bombast notwithstanding (1985, p. 301).

Institutions and specialization

The archaeological record of the EJ III-IV periods shows an explosion of large institutions in the form of monumental structures variously interpreted as temples or palaces. In many cases, the two appear closely linked, and a strict division between them may be inappropriate. Palaces were constructed of thick mud brick walls, sometimes on massive stone foundations, and organized around large open courtyards, some of which were paved with fired bricks. In most cases only fragments of larger complexes have been excavated, as at Ebla, 
Mozan, and Banat (Akkermans and Schwartz 2003, pp. 235-244; Buccellati 2005; Cooper 2006, pp. 128-130), but the central complex at Tell Beydar has been almost completely cleared and now restored (Lebeau and Suleiman 2003; Lebeau and Suleiman 2007). Other major palatial structures are known from Tell Bi'a, Tell Chuera, and Tell Brak (Emberling and McDonald 2003; Miglus and Strommenger 2007; Oates et al. 2001; Orthmann and Pruß 1995).

Temples attained a monumentality that was absent in the preceding EJ I-II periods, and show a remarkable variability across northern Mesopotamia. In western Syria, the Euphrates valley, the arid steppe margins, and as far east as Tell Chuera, temples retained the long room structure, now with two walls extending out beyond the entrance to create a porch (Castel and Peltenburg 2007, p. 606; Cooper 2006, pp. 150-159). A remarkable series of temples were built in close association with the EJ III central palace at Tell Beydar. In these multiroomed structures, the cella was a broad room, with a focal wall decorated with elaborate niches and plastering (Lebeau 2006). The two EJ IV temples at Tell Brak, on the other hand, are narrower long room cellas with a bent-axis approach from large courtyards (Oates and Oates 2001b). Where extensively excavated, these shrines are part of larger complexes that include features similar to those of domestic structures, albeit at institutional scale, which lends support to the idea that "temples" (an etic term) are better conceived as divine households (see below).

Craft production became highly standardized and specialized (Wattenmaker 1998). The elaborately and laboriously decorated fine wares of the Ninevite 5 tradition gave way to mass produced undecorated open bowl forms. The significance of this shift is debated. One interpretation emphasizes state control over pottery production; the standardized bowls were tools for ration distribution in a centralized political economy built around the redistribution of staples (Senior and Weiss 1992; Weiss and Courty 1993). Alternatively, the transition may have 
been related to increased manufacturing specialization, since a simpler open form was more easily stacked in the kiln and large batches could be fired simultaneously (Senior 1998; Stein and Blackman 1993). Pottery production appears not to have been centralized; a survey of the Tell Leilan region recovered wasters not only at Leilan itself but also on the surfaces of every contemporary site in its hinterland, regardless of size (Stein and Blackman 1993, pp. 40-41). The high frequency of open bowls might be related to new customs of food serving and communal consumption that encouraged all households to have many serving vessels (Ur and Colantoni in press). Likewise, production of flint blades was specialized but organized at the household level at Titriş Höyük (Hartenberger et al. 2000).

On the other hand, the manufacture and distribution of various wealth items was clearly controlled by powerful political institutions. At Ebla, precious metals and fine textiles were closely monitored by the royal household and were distributed to the kings of rival powers, their families, and their representatives (Archi 1996; Archi and Biga 2003; Mazzoni 2003). The evidence from Ebla is primarily textual, but elsewhere such elements of the political economy have survived in mortuary contexts. Elite burials show a dramatic change from the EJ I-II, when status differences were subtle. Particularly in the Euphrates valley, elite tombs contained an array of metals, imported stones, and other luxury items. Many of these structures were family tombs reused over the generations, and were at least initially above ground (Cooper 2006, pp. 223-237; Peltenburg 1999a; Schwartz et al. 2006). A unique burial mound at Tell Banat on the Syrian Euphrates, the "White Monument," will be discussed below.

In addition to luxury items, the wealth economy included the movement of high value animals. The Ebla texts reveal the value and importance of the kúnga equid, likely to have been a donkey-onager hybrid. These animals were raised on the plains of the Upper Khabur and sent 
as diplomatic gifts to Ebla by the king of Nagar (Tell Brak) (Archi 1998). Indeed equids appear to have been sacrificed and ritually buried in the FS temple complex at Brak (Clutton-Brock 2001). The twenty-six or more equids in the elite tombs at Umm el-Marra, a town in the kingdom of Ebla (Schwartz et al. 2006), may have originated from this trade (Weber 2008).

\section{Models for EJ III-IV society}

To understand the formation, operational dynamics, and dissolution of northern Mesopotamian polities, most researchers work within a culture historical approach that focuses on the remains of ruling institutions and emphasize the agency of kings and other high ranking elites. As a result, most sociopolitical models are heavily top-down, although emergent models are increasingly common.

The first model originated to explain the evolution of settlement and sociopolitical hierarchy at Tell Leilan but has been extended to cover the Upper Khabur basin (Weiss and Courty 1993; Weiss et al. 1993). According to Weiss and colleagues, the earliest state government at Leilan (late EJ II) manifested itself in the form of rapid urban expansion, as the 15 ha city grew to 90 ha. Urban form was centrally planned; the excavations in the lower town revealed a $4.5 \mathrm{~m}$ wide sherd-paved street without direct access to the residences that lined it (Weiss 1990). The staple economy was state-controlled via storerooms on the high mound that were filled with processed cereals (Weiss 2003; Weiss et al. 1993:997). State formation was externally stimulated in the context of interregional exchange in mineral resources between southern Mesopotamia and highland Anatolia (Calderone and Weiss 2003, p. 201).

Subsequently, in the EJ III period, the state institutionalized social and political inequalities by the construction of a wall around the high mound, intended to protect the elite and their wealth from the lower status residents of the town and its hinterland (Weiss and Courty 
1993, p. 138). The Ninevite 5 tradition of decorated ceramics was abandoned in favor of new mass-produced standardized forms used by the state for taxation and redistribution (Weiss 1997, p. 343). The even distribution of large centers at $25 \mathrm{~km}$ intervals, dendritic patterns of small settlements with their territories, and linear arrangements of sites is interpreted as "agroproduction optimizing locations" (Weiss 1992, p. 93). Political and economic centralization was further enhanced by the conquest of the northern plains by the rulers of the Akkadian dynasty of southern Mesopotamia in the EJ IV period. The impetus for this conquest was a postulated decrease in Euphrates river flow that necessitated the acquisition of staples from elsewhere; hence it was driven by a political economy based on staple finance (Senior and Weiss 1992; Weiss 1997, p. 343; Weiss 2003, p. 595; Weiss and Courty 1993, pp. 146-150). A similar centralized model has been applied the kingdom of Ebla in western Syria (Dolce 1998) and for agricultural redistribution at Titriş Höyük (Hald in press).

Few other reconstructions assume such pervasive social control, but powerful centralized authority may have resided behind the spatial layout of EJ III-IV cities and towns. Geophysical prospection at several urban sites has revealed a radial pattern of streets from a central high mound and circular outer city walls. The internal structure of Tell Chuera, for example, can be "nothing else but the result of preconceived central planning" (Meyer 2007, p. 137). A smaller town in a more marginal environment, Tell al-Rawda, may have been installed by some external power, possibly Ebla, according to a pre-formulated town plan that may have been based on Chuera (Castel and Peltenburg 2007, pp. 604, 613). Where large areas of domestic inhabitation have been exposed, regularities in the size of the street frontage and cross-street alignments of walls might indicate centralized planning (Matney and Algaze 1995, pp. 48-49; Pfälzner 2001). A recent review of the evidence for settlement organization proposes varying degrees of 
planning, with central authorities frequently involved in street layout and city wall construction but rarely with the internal arrangement of neighborhoods (Creekmore 2008).

Others see a more decentralized political structure, with urbanism as at least a partially emergent product, particularly in comparison to the urban polities of southern Mesopotamia. Although elements of southern ideology and administrative technologies were adopted, Stein (2004) sees the absence of monumental propagandistic art, the smaller scale of palace and temple institutions, and a significant political role for assemblies as evidence for a more tribal organization in northern Mesopotamian polities (see also Stein 1994). The combination of tribal or segmentary organization and the option to adopt a mobile pastoralist lifeway subjected northern Mesopotamian cities to strong centrifugal forces (Stein 2004, pp. 77-78).

Another decentralized model (Ur 2004; Ur 2009) envisions EJ III-V society as a dynamic arrangement of nested households by combining the staple economic model of Wilkinson (1994) with David Schloen's Patrimonial Household Model of Bronze Age society in the Near East (2001). Schloen's review of indigenous terminology in the cuneiform record demonstrates that the large institutions we label as "palaces" and "temples" were largely organized along the metaphor of the household. The relationships within and between such institutional households were framed in terms of kinship, rather than the rational bureaucratic terminology most often used in archaeological and epigraphic reconstructions. The "state" itself (a concept for which no term exists in Sumerian or Akkadian; see Emberling 2003, pp. 260-261) was the household of the king, or in some cases of a god. Patrimonial household (oikos) organization is particularly clear in EJ III period Ebla and southern Mesopotamia (Pollock 1999; Renger 2003; Renger 1995, pp. 267-283; Schloen 2001, pp. 262-283). Large territorial polities are inherently unstable and require the close maintenance of the interpersonal relationships that form them. These 
relationships are often negotiated and renegotiated in contexts of commensal eating and drinking (Dietler 2003, pp. 271-272). Within the patrimonial social network that in aggregate composed EJ III-IV cities, such necessities may have driven intensification and surplus production, rather than coercion by a powerful state (Ur and Colantoni in press).

The above models can be critiqued for overly emphasizing hierarchically organized sedentary society at the expense of mobile pastoral groups. Such groups were economically and politically important in the Middle Bronze Age and later, as revealed by textual sources (Durand 2004; Fleming 2004). The Kranzhügel sites in the steppe may have originated as gathering places for mobile groups (Kouchoukos 1998; Lyonnet 1998). Based on the excavations at Tell Banat on the Syrian Euphrates, Anne Porter has proposed a corporate model whereby pastoral nomadic groups established and maintained group identity around highly visible burials of tribal ancestors (Porter 2002; 2004). Banat initially took its form as a ritual center around multiple burials but eventually only the White Monument, a multi-phase tumulus-like structure which grew in part through the addition of disarticulated human remains, continued to be maintained, a circumstance that might signal the consolidation of power to a single descent line whose apical ancestors were buried within it (McClellan 1998; Porter 2002, pp. 25-28). Although speculative, Porter's model rightly stresses the artificiality of the pastoralist-sedentary agriculturalist dichotomy, and corporate forms as alternative and co-existing sociopolitical arrangement (Porter 2004).

These more decentralized reconstructions distribute agency not only to the heads of elite institutional households but also to the small individual households that made up the bulk of society, be they sedentary or nomadic. In an attempt to model the emergent effects of aggregated decision-making within such households, Wilkinson, Christiansen and colleagues have created 
an agent-based computer model for a hypothetical EJ III settlement, loosely based on Tell Beydar and its hinterland (Christiansen and Altaweel 2006; Wilkinson et al. 2007a; 2007b). Wilkinson's initial agricultural assumptions (reviewed above) have been combined with climatic, pastoral, demographic, and social variables in an agent-based social modeling framework. Various iterations of the model suggest that small settlements could survive most difficulties (for example, multi-year drought, reduction in plow animals or human labor, or crop blight) by adjusting patterns of land use or by drawing on networks of kin relations for exchange. They conclude that "high amplitude inputs (e.g., rainfall) may be absorbed by social factors to result in low-amplitude outputs (i.e., population)" and that EJ III settlements were more resilient in the face of climatic adversity than is generally assumed (Wilkinson et al. 2007a, p. 66).

These models have been presented on a continuum from those that are the most centralized, with decision making limited to one or a few individuals at the top of a strongly hierarchical society, to those that attempt to incorporate the motivations and actions of a wider range of social groups and individuals. In the second half of the third millennium, the nature of urban society varied in time and space across northern Mespotamia; we should expect phases of centralization under one or a few strong urban institutions, alternating with times of decentralization when several such institutions competed for political power and economic control, at the regional scale and within cities. The Patrimonial Household Model (Schloen 2001) is capable of describing such dynamism, and does so with reference to emically meaningful social terminology. The most top-down oriented models, particularly those that posit centralized control over almost all aspects of settlement and production, are difficult to accept; none can explain why non-elites would stand for such tyranny when a transition to a mobile pastoral existence always remained a possibility (Adams 1978). Top-down forces certainly did 
exist and put a stamp on urban society, particularly clear in the form of monumental city walls, palaces, religious instititions, and possibly some aspects of urban planning. We must remember, however, that these large-scale products of the centralized phases, quite possibly brief, are prone to outlast the more ephemeral networks of social relationships responsible for their construction. As archaeologists continue to evaluate royal inscriptions more critically and explore a wider range of socioeconomic contexts via excavation, strongly top-down models are likely to be increasingly replaced by reconstructions that appreciate the fragility of political centralization and the ability of uncoordinated actions by individuals to create structures and effect change.

\section{Agricultural intensification, climatic variability, and urban collapse, ca. 2200-2000 BC}

At the end of the third millennium BC, the cities of northern Mesopotamia were depopulated, in some cases permanently, within the span of a single ceramic phase. When later settlement is to be found on these sites, in most cases it represents a clean break from the third millennium levels. Almost all aspects of this transition are debated. Some scholars propose that abandonment was complete and simultaneous across northern Mesopotamia at the end of the EJ IV period, as the result of an abrupt aridification event resulting from volcanic activity (Courty and Weiss 1997; Weiss and Courty 1993; Weiss et al. 1993) or due to changes in atmospheric circulation patterns (Staubwasser and Weiss 2006). In these scenarios, the event caused not only the collapse of the Akkadian empire in the north but also its dissolution in its southern homeland at the hands of sedentary and nomadic groups who had been displaced by the deterioration of environmental conditions. More recently, it has been proposed that almost every archaeologically documented Old World civilization either collapsed or faced extreme stress due to this event (Courty and Weiss 1997; de Menocal 2001; Staubwasser and Weiss 2006, pp. 380383; Weiss 2000). 
The nature and timing of this proposed aridification event has been revised on the basis of the Tell Brak stratigraphy, where the event's micromorphological signature occurs in strata dating to the beginning of the EJ IV, rather than its end, which poses a challenge to the climate collapse hypothesis for the Akkadian empire (Courty 2001). Furthermore, it is now attributed to an extraterrestrial impact event rather than a volcano (Courty 1998; Courty 1999).

Other explanations see collapse resulting from a combination of climate and nonsustainable land use. The staple economies of the largest settlements operated close to the limits of sustainability, and could collapse when faced with a run of dry years (Wilkinson 1994; Wilkinson 1997). Smaller settlements could weather such droughts through a combination of exchange and the extension of agricultural cultivation, but urban centers near the 100 ha size threshold, which were already cultivating all of the available land, could not (Wilkinson et al. 2007a, pp. 65-66).

The initial publication of the abrupt climatic event hypothesis (Weiss et al. 1993) inspired substantial investigation into the nature of this transition at the end of the 3rd millennium (Kuzucuoğlu and Marro 2007), and it is now clear that to some extent, the appearance of widespread abandonment in the EJ V period resulted from a gap in the archaeological dataset. While it was true at one point that no major structures or pottery assemblages for this phase were known (Weiss and Courty 1993, pp. 141-142), ceramic chronology is now much improved and EJ V settlement is well documented at almost all of the major urban sites (Dohmann-Pfälzner and Pfälzner 2001; Koliński 2007; McMahon 1998; Oates et al. 2001; Oates and Oates 2001c; Tunca et al. 2007), although it is often of a different nature than the EJ III-IV settlement that preceded it. These new data show that the timing of the urban collapse varied throughout northern Mesopotamia, and that some areas may not have been abandoned at all (Akkermans and 
Schwartz 2003, pp. 284-287; Marro and Kuzucuoğlu 2007; Peltenburg 2007b Table 1.1;

Schwartz 2007).

\section{Conclusions and future directions}

From the end of the 5th to the end of the 3rd millennium BC, Northern Mesopotamian civilization experienced cycles of expansion and contraction, in terms of urbanization, political centralization, growth of institutions, and various aspects of economic organization. The reemergence of social complexity in the later 3rd millennium was not, however, merely a return to an earlier stage. The initial phase (ca. 4400-3400 BC) was geographically uneven and characterized by gradual development (Fig. 2). Emergent population agglomeration was limited to the Upper Khabur basin and surrounding plains. Although they developed sophisticated productive technologies, particularly in the area of metallurgy, the 4th millennium riverine settlements lacked social institutions capable of counteracting processes of settlement fissioning prior to the Uruk expansion. The large indigenous settlements that did develop, in particular Tell Brak and Khirbat al-Fakhar, were isolated and heavily primate centers with few scalar intermediaries between themselves (55 ha and 300 ha, respectively) and their village/hamlet neighbors. The duration of Khirbat al-Fakhar's extensive settlement is uncertain, but Brak witnessed a steady growth over seven or eight centuries before colonists from southern Mesopotamia arrived.

After the phase of deurbanization at the beginning of the millennium, cities reemerged in northern Mesopotamia in a much different form around 2500 BC. The settlements themselves were nucleated and densely occupied, sometimes walled, and most of them appeared rapidly. Furthermore, they were not limited to the broad alluvial plains; urban places now appeared in the river valleys and even on the edge of the steppes, albeit at a smaller scale and with less 
frequency.

Thus the two cycles of expanded social complexity and collapse in the 4th and late $3 \mathrm{rd}$ millennia $\mathrm{BC}$ have broad similarities in aspects of specialization and mass production, population agglomeration, and monumental architecture that probably hosted institutional-scale secular or religious households. The differences between these cycles, however, suggest corresponding differences in the underlying forces responsible for their creation. Fourth millennium urban society was restricted to only a few places and showed characteristics of experimentation, particularly in the "proto-urban" phase of the LC1-2 periods. The developments at Brak and Khirbat al-Fakhar unfolded over almost a millennium. On the other hand, the reurbanization of the later 3rd millennium was sudden, geographically widespread, and archaeologically simultaneous (emerging over the course of two centuries at most) at a number of nucleated sites that differed from the more dispersed 4th millennium pattern. In this case, rather than experimentation, we see adherence to a general template of what a city and its institutions should look like. Fourth millennium urbanism appears almost accidental, the emergent result of unplanned forces that brought people together and then kept them there; by the 3rd millennium, on the other hand, the city and its institutions were known quantities, things that could be envisioned and purposefully created. The northern Mesopotamians' urban model might have come from an oral tradition of 4th millennium Tell Brak but is more likely to have been inspired by interaction with people from southern Mesopotamia and exposure to their urban places, which appears not to have experienced the same process urban dissolution in the early 3rd millennium.

At the present state of knowledge, the initial cycle of urban civilization in northern Mesopotamia appears to be a case of a non-linear social developmental trajectory, whose end 
results (most prominently, large population concentrations at Brak and Khirbat al-Fakhar) were not forseen by individual actors and households, who were entirely concerned with decision making to achieve their own short-term goals. The institutions and settlement forms that emerged from the totality of these actions may have been largely unintentional, but now having existed, could then be purposefully replicated.

Such purposeful replication is probably responsible for the second cycle of urbanism, beginning ca. 2600-2500 BC. One might be tempted to interpret the rapidity and apparent uniformity of urban reemergence as a sign of an imposed or planned aspect to these places, as has been argued for Tell Leilan and the Kranzhügel sites (Meyer 2007; Weiss et al. 1993). On the other hand, some key characteristics of later urban society were already in existence in the earlier 3rd millennium, for example dense settlement fabric and property-controlling religious institutions (Matthews 2002; Schwartz 1994b). With the development of fission-retarding social institutions, most likely the metaphorical extension of the household to encompass neighborhoods, settlements, or even entire kingdoms (Schloen 2001), widely shared local rules of social interaction and spatial arrangement may have conspired to produce the global order of 3rd millennium urbanism. The idea that cities might be understood as hypertrophic villages has also been proposed for the contemporary southern Mesopotamia (Steinkeller 2007, pp. 201-205). Northern Mesopotamian cities of the later 3rd millennium were not entirely emergent products; certainly institutional households and their rulers played significant roles. However, their actions were probably constrained by unanticipated emergent processes (e.g., erecting a city wall around an already-expanded urban settlement, or formalizing a preexisting urban thoroughfare) rather than structuring (e.g., the wholesale construction of the Neo-Assyrian imperial capitals of the 1st millennium BC). 
Despite a disciplinary tendency to view southern Mesopotamia as the heartland of urbanism and political centralization, northern Mesopotamian civilization developed largely on its own trajectory, although not in isolation. The extensive settlements on the northern plains predated the beginnings of the Uruk expansion by half a millennium or more, and they retained little of its influence after its collapse (Frangipane 2007c). The 3rd millennium urban resurgence occurred at a time when southern cities had been flourishing for centuries, and some aspects of elite material culture, particularly administrative technologies, appear to have been adapted for local use, but again it preceded well documented interactions during and immediately preceding the Akkadian conquest, in whatever form it took. Southern and northern Mesopotamia did not evolve in isolation, but with the exception of the time of the Uruk expansion, the cultural aspects that were exchanged were translated into local meanings rather than adopted wholesale (Stein 2004).

Future prospects

Although our understanding of these social developments has grown exponentially in the last decades, there are still considerable lacunae. In geographic terms, coverage is highly uneven. For example, dam salvage projects have resulted in an overemphasis on riverine landscapes, which were important loci during the Uruk expansion but appear to have been marginal or vacant regions when considering indigenous development. On alluvial plains, only the largest sites have been targeted for excavation; the tail of the settlement system is known only from surface survey. It is difficult therefore to speak of the specialized functions of these urban places when none of the non-urban settlements in their hinterlands can be demonstrated to have lacked them. Archaeologists' abilities to address this imbalance are hampered by the priorities of national antiquities services, whose primary concerns often relate to mitigation and 
the tourist economy.

The greatest geographical lacuna is, of course, the continued research hiatus in Iraq. The plains around the Jebel Sinjar and the eastern banks of the Tigris undoubtedly have much to contribute to these debates (Rothman 2001b). Iraqi archaeologists have recently published some brief results of work from the 1980s but the political situation remains so dire that they do so anonymously (Altaweel 2006; 2007).

Although the culture historical approach still predominates, scholarship has become increasingly concerned with how societies worked and why they changed. The best example is the Tell Leilan-based model of state formation and urban collapse (Weiss and Courty 1993; Weiss et al. 1993), which foregrounded issues of staple economics, urban planning, and above all the role of climate change. This provocative and controversial model has largely set the agenda for subsequent research (e.g., Kuzucuoğlu and Marro 2007). New modeling technologies now allow agent-based computer models to be constructed and run against the archaeological record (Wilkinson et al. 2007a; 2007b). Nonetheless, the further subdivision of time continues to be a strong focus, although it is not always clear what, if any, research questions are driving it.

Northern Mesopotamian archaeology has begun to move beyond exclusive focus on elite contexts. Holistic approaches at the regional level have drawn on landscape archaeology, regional settlement survey, and satellite remote sensing; this approach is best articulated in the work of Tony Wilkinson (2003). At the site level, intensive surface collection and geophysical prospection have revealed spatial organization, planning, and activities of elite and commoner alike; increasingly, these studies have been followed up by horizontal exposures of non-elite and non-monumental areas, exemplified by the work at late 3rd millennium Titriş Höyük in Turkey (Algaze et al. 2001; Matney and Algaze 1995; see also Pfälzner 2001). Micro-morphological 
and micro-archaeological innovations have revealed the range of activities within such households (Matthews 2003b; Matthews et al. 2001; Rainville 2005). Not surprisingly, these methodological trends have coincided with the development of less centralized models of urban society that attribute agency to others besides a few elites. Nonetheless, even at urban sites there frequently remains a reticence to devote resources to the excavation of non-elite contexts.

It is quite likely that when research can be again conducted in the so-called "core" of southern Mesopotamia, it will employ new methods developed in, and be driven by research questions derived from, the highly productive past two decades of fieldwork in northern Mesopotamia, to which it is increasingly difficult to apply the term "periphery." 


\section{Acknowledgements}

This review made use of two excellent research facilities and their online resources that I am happy to acknowledge here: Harvard University's Tozzer Library (especially Janet Steins and Emily Moss) and its Anthropological Literature database; and the University of Chicago Oriental Institute's Research Archives, its Research Archivist Foy Scalf, and its online catalog (http://oilib.uchicago.edu). Many of the ideas presented here were soundly critiqued by Harvard graduate students enrolled in Anthropology 2065: Complex Societies of Northern Mesopotamia in Spring 2008. This manuscript benefited from comments and corrections from Guillermo Algaze, Frank Hole, Anne Porter, Philip Karsgaard, Emily Hammer, and four anonymous reviewers. 


\section{References cited}

Adams, R. M. (1978). Strategies of maximization, stability, and resilience in Mesopotamian society, settlement, and agriculture. Proceedings of the American Philosophical Society 122: $329-335$.

Akhundov, T. (2007). Sites de migration venus du Proche-Orient en Transcaucasie. In Lyonnet, B. (ed.) Les cultures du Caucase (VIe-IIIe millénaires avant notre ère): Leur relations avec le Proche-Orient, Éditions Recherche sur les Civilisations, Paris, pp. 95-121.

Akkermans, P. M. M. G. and Duistermaat, K. (1997). Of storage and nomads: The sealings from late neolithic Sabi Abyad, Syria. Paléorient 22: 17-44.

Akkermans, P. M. M. G. and Schwartz, G. (2003). The Archaeology of Syria: From Complex Hunter-Gatherers to Early Urban Societies (ca. 16,000-300 BC), Cambridge University Press, Cambridge.

Algaze, G. (1993). The Uruk World System, University of Chicago Press, Chicago.

Algaze, G. (1999). Trends in the archaeological development of the upper Euphrates basin of southeastern Anatolia during the late chalcolithic and early bronze ages. In del Olmo Lete, G. and Montero Fenollós, J.-L. (eds.), Archaeology of the Upper Syrian Euphrates: The Tishrin Dam Area, Editorial Ausa, Barcelona, pp. 535-572.

Algaze, G. (2001). Initial social complexity in southwestern Asia: The Mesopotamian advantage. Current Anthropology 42: 199-233.

Algaze, G. (2008). Ancient Mesopotamia at the Dawn of Civilization, University of Chicago, Chicago and London. 
Algaze, G., Breuninger, R. and Knudstad, J. (1994). The Tigris-Euphrates Archaeological Reconnaissance Project: Final report of the Birecik and Carchemish dam survey areas. Anatolica 20: 1-96.

Algaze, G., Dinckan, G., Hartenberger, B., Matney, T., Pournelle, J., Rainville, L., Rosen, S., Rupley, E., Schlee, D. and Vallet, R. (2001). Research at Titriş Höyük in southeastern Turkey: The 1999 season. Anatolica 27: 23-106.

Altaweel, M. (2004). The roads of Ashur and Nineveh. Akkadica 124: 221-228.

Altaweel, M. (2006). Excavations in Iraq: The Ray Jazirah project, first report. Iraq 69: 155-181.

Altaweel, M. (2007). Excavations in Iraq: The Jazirah Salvage project, second report. Iraq 69: $117-144$

Archi, A. (1996). Les comptes rendus annuels de métaux. In Durand, J.-M. (ed.) Mari, Ebla et les Hourrites, ERC, Paris, pp. 73-99.

Archi, A. (1998). The regional state of Nagar according to the texts of Ebla. In Lebeau, M. (ed.) About Subartu: Studies Devoted to Upper Mesopotamia, Brepols, Turnhout, pp. 1-15.

Archi, A. and Biga, M. G. (2003). A Victory over Mari and the Fall of Ebla. Journal of Cuneiform Studies 55: 1-44.

Ball, W. (1997). Tell Shelgiyya: An early Uruk "Sprig Ware" manufacturing and exporting centre on the Tigris. al-Rafidan 17: 93-104.

Ball, W., Tucker, D. and Wilkinson, T. J. (1989). The Tell al-Hawa project: Archaeological investigations in the north Jazira. Iraq 51: 1-66.

Ball, W. and Wilkinson, T. J. (2003). Ninevite 5 town and country in northwestern Iraq. In Rova, E. and Weiss, H. (eds.), The Origins of North Mesopotamian Civilization: Ninevite 5 Chronology, Economy, Society, Brepols, Turnhout, pp. 335-359. 
Biga, M. G. (1998). The marriage of Eblaite princess Tagrish-Damu with a son of Nagar's king. In Lebeau, M. (ed.) About Subartu: Studies Devoted to Upper Mesopotamia, BREPOLS, Turnhout, pp. 17-39.

Buccellati, G. (2005). The monumental urban complex at Urkesh: Report on the 16th season of excavations, July-September 2003. In Owen, D. I. and Wilhelm, G. (eds.), Studies on the Civilization and Culture of Nuzi and the Hurrians, Volume 15: General Studies and Excavations at Nuzi 11/1, CDL Press, Bethesda MD, pp. 3-28.

Buccellati, G. and Kelly-Buccellati, M. (2002). Tar'am-Agade, daughter of Naram-Sin, at Urkesh. In al-Gailani Werr, L., Curtis, J., Martin, H., McMahon, A., Oates, J. and Reade, J. (eds.), Of Pots and Plans: Papers on the Archaeology and History of Mesopotamia and Syria Presented to David Oates in Honour of his 75th Birthday, Nabu, London, pp. 1131.

Butterlin, P. (2003). Les temps proto-urbains de Mésopotamie: contacts et acculturation à l'époque d'Uruk au Moyen-Orient, CNRS, Paris.

Calderone, L. and Weiss, H. (2003). The end of the Ninevite 5 period at Tell Leilan. In Rova, E. and Weiss, H. (eds.), The Origins of North Mesopotamian Civilization: Ninevite 5 Chronology, Economy, Society, Brepols, Turnhout, pp. 193-220.

Castel, C. and Peltenburg, E. (2007). Urbanism on the margins: Third millennium BC al-Rawda in the arid zone of Syria. Antiquity 81: 601-616.

Cauvin, M. C., Gourgaud, A., Gratuze, B., Arnaud, N., Poupeau, G., Poidevin, J.-L. and Chataigner, C. (eds.) (1998). L'obsidienne au Proche et Moyen Orient: Du volcan à l'outil, Archaeopress, Oxford. 
Charles, M. and Bogaard, A. (2001). Third-Millennium BC Charred Plant Remains from Tell Brak. In Oates, D., Oates, J. and McDonald, H., Excavations at Tell Brak, Vol. 2: Nagar in the Third Millennium BC. McDonald Institute for Archaeological Research and the British School of Archaeology in Iraq, Cambridge and London, pp. 301-326.

Christiansen, J. H. and Altaweel, M. R. (2006). Understanding ancient societies: A new approach using agent-based holistic modeling. Structure and Dynamics: eJournal of Anthropological and Related Sciences 1: Article 7.

Clutton-Brock, J. (2001). Ritual burials of a dog and six domestic donkeys. In Oates, D., Oates, J. and McDonald, H., Excavations at Tell Brak, Vol. 2: Nagar in the Third Millennium BC. McDonald Institute for Archaeological Research and the British School of Archaeology in Iraq, Cambridge and London, pp. 327-338.

Colantoni, C. (2005). Traces of Tradition: Northern Mesopotamian Urbanism from the Late 3rd through Early 2nd Millennium BC, Ph.D. dissertation, Department of Archaeology, Cambridge University, Cambridge.

Collins, P. (2000). The Uruk phenomenon: The role of social ideology in the expansion of the Uruk culture during the fourth millennium BC, Archaeopress, Oxford.

Cooper, L. (2006). Early Urbanism on the Syrian Euphrates, Routledge, New York and London. Courty, M. A. (1998). The soil record of an exceptional event at 4000 BP in the Middle East. In Peiser, B. J., Palmer, T. and Bailey, M. E. (eds.), Natural Catastrophes during Bronze Age Civilizations, Archaeopress, Oxford, pp. 93-108.

Courty, M. A. (1999). The 4000 yr BP impact event: The birth of a scientific hypothesis. The Observatory, A Review of Astronomy 119: 168-171. 
Courty, M. A. (2001). Evidence at Tell Brak for the late EDIII/early Akkadian air blast event (4 kyr BP). In Oates, D., Oates, J. and McDonald, H., Excavations at Tell Brak, Vol. 2: Nagar in the Third Millennium BC. McDonald Institute for Archaeological Research and the British School of Archaeology in Iraq, Cambridge and London, pp. 367-372.

Courty, M. A. and Weiss, H. (1997). The scenario of environmental degradation in the Tell Leilan region, NE Syria, during the late third millennium abrupt climate change. In Dalfes, H. N., Kukla, G. and Weiss, H. (eds.), Third Millennium BC Climate Change and Old World Collapse, Springer-Verlag, Berlin and Heidelberg, pp. 107-147.

Cowgill, G. L. (2004). Origins and development of urbanism: Archaeological perspectives. Annual Review of Anthropology 33: 525-549.

Creekmore, A. (2008). Kazane Höyük and Urban Life Histories in Third Millennium Upper Mesopotamia, PhD dissertation, Department of Anthropology, Northwestern University, Evanston, IL.

Danti, M. (2000). Early Bronze Age Settlement and Land Use in the Tell es-Sweyhat Region, Syria, Ph.D. dissertation, Department of Anthropology, University of Pennsylvania, Philadelphia.

Danti, M. and Zettler, R. L. (2007). The early bronze age in the Syrian north-west Jezireh: The Tell es-Sweyhat region. In Peltenburg, E. (ed.) Euphrates River Valley Settlement: The Carchemish Sector in the Third Millennium BC, Oxbow Books, Oxford, pp. 164-183. de Lillis Forrest, F., Milano, L. and Mori, L. (2007). The Akkadian occupation in the northwest area of the Tell Leilan acropolis. Kaskal 4: 43-64.

de Menocal, P. (2001). Cultural responses to climate change during the late Holocene. Science 292: $667-673$. 
del Olmo Lete, G. and Montero Fenollós, J.-L. (eds.) (1999). Archaeology of the Upper Syrian Euphrates: The Tishrin Dam Area, Editorial Ausa, Barcelona.

Dietler, M. (2003). Clearing the table: Some concluding reflections on commensal politics and imperial states. In Bray, T. L. (ed.) The Archaeology and Politics of Food and Feasting in Early States and Empires, Kluwer, New York, pp. 271-282.

Dohmann-Pfälzner, H. and Pfälzner, P. (2001). Ausgrabungen der Deutschen Orient-Gesellschaft in der zentralen Oberstadt von Tall Mozan/Urkeš: Bericht über die in Kooperation mit dem IIMAS durchgeführte Kampagne 2000. Mitteilungen der Deutschen OrientGesellschaft zu Berlin 133: 97-139.

Dolce, R. (1998). The palatial Ebla culture in the context of north Mesopotamia and north Syrian main powers. In Lebeau, M. (ed.) About Subartu: Studies Devoted to Upper Mesopotamia, Brepols, Turnhout, pp. 67-81.

Durand, J.-M. (2004). Peuplement et sociétés à la époque amorrite: (1) les clans bensim'alites. In Nicolle, C. (ed.) Nomades et sédentaires dans le Proche-Orient ancien, Editions Recherche sur les civilisations, Paris, pp. 111-197.

Eidem, J., Finkel, I. and Bonechi, M. (2001). The Third Millennium Inscriptions. In Oates, D., Oates, J. and McDonald, H., Excavations at Tell Brak, Vol. 2: Nagar in the Third Millennium BC. McDonald Institute for Archaeological Research and the British School of Archaeology in Iraq, Cambridge and London, pp. 99-120.

Emberling, G. (2002). Political control in an early state: The Eye Temple and the Uruk expansion in northern Mesopotamia. In al-Gailani Werr, L., Curtis, J., Martin, H., McMahon, A. and Reade, J. (eds.), Of Pots and Plans: Papers on the Archaeology and 
History of Mesopotamia and Syria Presented to David Oates in Honour of his 75th Birthday, Nabu Publications, London, pp. 82-90.

Emberling, G. (2003). Urban social transformations and the problem of the 'first city': New research from Mesopotamia. In Smith, M. L. (ed.) The Social Construction of Ancient Cities, Smithsonian Institution, Washington and London, pp. 254-268.

Emberling, G., Cheng, J., Larsen, T. E., Pittman, H., Skuldbøl, T. B. B., Weber, J. and Wright, H. T. (1999). Excavations at Tell Brak 1998: Preliminary report. Iraq 61: 1-41.

Emberling, G. and McDonald, H. (2001). Excavations at Tell Brak 2000: Preliminary report. Iraq 63: 21-54.

Emberling, G. and McDonald, H. (2003). Excavations at Tell Brak 2001-2002: Preliminary report. Iraq 65: 1-75.

Englund, R. K. (1998). Texts from the late Uruk period. In Attinger, P. and Wäfler, M. (eds.), Mesopotamien: Späturuk-Zeit und frühdynastische Zeit, Universitätsverlag Freiburg, Vandenhoeck \& Ruprecht, Freiburg and Göttingen, pp. 15-233.

Evans, J. M. (2007). The square temple at Tell Asmar and the construction of Early Dynastic Mesopotamia, ca. 2900-2350 B.C. American Journal of Archaeology 111: 599-632. Felli, C. (2003). Developing complexity. Mid to late fourth-millennium investigations: The Northern Middle Uruk period. In Matthews, R. (ed.) Excavations at Tell Brak Vol. 4: Exploring an Upper Mesopotamian Regional Centre, 1994-1996, McDonald Institute and British School of Archaeology in Iraq, Cambridge and London, pp. 53-95.

Finkbeiner, U. (ed.) (1991). Uruk Kampagne 35-37 1982-1984: Die archäologische Oberflächenuntersuchung (Survey), Philipp von Zabern, Mainz am Rhein. 
Fleming, D. E. (2004). Democracy's Ancient Ancestors: Mari and Early Collective Governance, Cambridge University Press, Cambridge and New York.

Forest, J.-D. (2001). De l'anecdote à la structure: l'habitat de la culture de Gawra et la chefferie nord-mesopotamienne. In Breniquet, C. and Kepinski, C. (eds.), Études Mesopotamiennes: Recueil de textes offert à Jean-Louis Huot, Editions Recherche sur les Civilisations, Paris, pp. 177-196.

Fortin, M. (2000). Economie et sociéte dans la moyenne vallée du Khabour durant la période de Nineve V. In Rouault, O. and Wäfler, M. (eds.), La Djéziré et l'Euphrate syriens de la protohisoire à la fin du IIe millénaire av. J.C, Brepols, Turnhout, pp. 229-242.

Frangipane, M. (ed.) (2007a). Arslantepe Cretulae: An Early Centralized Administrative System Before Writing, Università di Roma La Sapienza, Rome.

Frangipane, M. (2007b). The Development of an Early State System without Urbanisation. In Frangipane, M. (ed.) Arslantepe Cretulae: An Early Centralized Administrative System Before Writing, Università di Roma La Sapienza, Rome, pp. 469-477.

Frangipane, M. (2007c). Establishment of a Middle/Upper Euphrates Early Bronze I Culture from the Fragmentation of the Uruk World: New Data from Zeytinli Baçe Höyük (Urfa, Turkey). In Peltenburg, E. (ed.) Euphrates River Valley Settlement: The Carchemish Sector in the Third Millennium BC, Oxbow Books, Oxford, pp. 122-141.

Frangipane, M., Di Nocera, G. M., Hauptmann, A., Morbidelli, P., Palmieri, A., Sadori, L., Schultz, M. and Schmidt-Schultz, T. (2001). New symbols of a new power in a 'royal' tomb from 3000 BC: Arslantepe, Malatya (Turkey). Paléorient 27: 105-139. 
Geyer, B. and Monchambert, J.-Y. (eds.) (2003). La basse vallée de l'Euphrate syrien du Néolithique à l'avènement de l'Islam: Géographie, archéologie et histoire, Institut Français d'Archéologie du Proche-Orient, Beirut.

Gibson, M., al-Azm, A., Reichel, C., Quntar, S., Franke, J. A., Khalidi, L., Hritz, C., Altaweel, M., Coyle, C., Colantoni, C., Tenney, J., Abdul Aziz, G. and Hartnell, T. (2002a). Hamoukar: A summary of three seasons of excavation. Akkadica 123: 11-34.

Gibson, M., Maktash, M., Franke, J. A., al-Azm, A., Sanders, J. C., Wilkinson, T. J., Reichel, C., Ur, J. A., Sanders, P., Salameh, A., Hritz, C., Watkins, B. and Kattab, M. (2002b). First season of Syrian-American investigations at Hamoukar, Hasekeh province. Iraq 64: 4568.

Gondet, S. and Castel, C. (2004). Prospection géophysique à al-Rawda et urbanisme en Syrie au bronze ancien. Paléorient 30: 93-110.

Gut, R. V. (1995). Das prähistorische Ninive: zur relativen Chronologie der frühen Perioden Nordmesopotamiens, Philipp von Zabern, Mainz am Rhein.

Gut, R. V. (2002). The significance of the Uruk sequence at Nineveh. In Postgate, J. N. (ed.) Artefacts of Complexity: Tracking the Uruk in the Near East, British School of Archaeology in Iraq, Warminster, pp. 17-48.

Hald, M. M. (in press). Distribution of crops at late Early Bronze Age Titriş Höyük, southeast Anatolia: towards a model for the identification of consumers of centrally organised food distribution. Vegetation History and Archaeobotany.

Hald, M. M. and Charles, M. (2008). Storage of crops during the fourth and third millennia BC at the settlement mound of Tell Brak, northeast Syria. Vegetation History and Archaeobotany 17: S35-S41. 
Hartenberger, B., Rosen, S. and Matney, T. (2000). The early bronze age blade workshop at Titriş Höyük: Lithic specialization in an urban context. Near Eastern Archaeology 63: $51-58$.

Hole, F. (1991). Middle Khabur settlement and agriculture in the Ninevite 5 period. Bulletin of the Canadian Society for Mesopotamian Studies 21: 17-29.

Hole, F. (1997). Evidence for mid-Holocene environmental change in the western Khabur drainage, northeastern Syria. In Dalfes, H. N., Kukla, G. and Weiss, H. (eds.), Third Millennium BC Climate Change and Old World Collapse, Springer Verlag, Berlin, pp. $39-66$.

Hole, F. (1999). Economic implications of possible storage structures at Tell Ziyadeh, NE Syria. Journal of Field Archaeology 26: 267-283.

Hole, F. (2000a). The prehistory of the Khabur. In Rouault, O. and Wäfler, M. (eds.), La Djéziré et l'Euphrate Syriens de la protohistoire à la fin du IIe millénaire av. J.-C.: Tendances dans l'interprétation historique des donnés nouvelles, Brepols, Turnhout, pp. 17-27.

Hole, F. (2000b). Tell Ziyadeh on the middle Khabur, Syria. In Matthiae, P., Enea, A., Peyronel, L. and Pinnock, F. (eds.), Proceedings of the First International Congress on the Archaeology of the Ancient Near East, Rome, pp. 609-19.

Hole, F. (2001). A radiocarbon chronology for the middle Khabur, Syria. Iraq 63: 67-98.

Ismail, F., Sallaberger, W., Talon, P. and Van Lerberghe, K. (1996). Administrative Documents from Tell Beydar (Seasons 1993-1995), Brepols, Turnhout.

Karsgaard, P. and Sołtysiak, A. (2007). The Autumn 2006 rescue operations at Tell Majnuna. Iraq 69: 157-158. 
Kepinski-Lecomte, C. (2001). Tell Khoshi et l'urbanisation de la Djezireh au IIIe millénaire. In Breniquet, C. and Kepinski, C. (eds.), Études Mésopotamiens: Recueil de textes offert à Jean-Louis Huot, Éditions Recherche sur les Civilisations, Paris, pp. 265-286.

Kepinski, C. (2007). Continuity and break at the end of the third millennium BC: The data from Tilbeşar, Sajur Valley (south-eastern) Turkey. In Kuzucuoğlu, C. and Marro, C. (eds.), Sociétés humaines et changement climatique à la fin du troisième millénaire: une crise at-elle eu lieu en haute Mésopotamie?, Institut Français d'études anatoliennes GeorgesDumézil, Istanbul, pp. 329-340.

Khalidi, L. (n.d.). Late chalcolithic lithic assemblage at Tell Hamoukar's southern extension. In Reichel, C. (ed.) The Origins and Development of Urbanism in NE Syria: The 2001-2007 Seasons at Hamoukar, Oriental Institute, Chicago.

Khalidi, L., Gratuze, B. and Boucetta, S. (in press). Provenance of obsidian excavated from late chalcolithic levels at the sites of Tell Hamoukar and Tell Brak, Syria. Archaeometry 7.

Koliński, R. (2007). The upper Khabur region in the second part of the third millennium BC. Altorientalische Forschungen 34: 342-369.

Kouchoukos, N. (1998). Landscape and Social Change in Late Prehistoric Mesopotamia, Ph.D. dissertation, Department of Anthropology, Yale University, New Haven.

Kuzucuoğlu, C. and Marro, C. (eds.) (2007). Sociétés humaines et changement climatique à la fin du troisième millénaire: une crise a-t-elle eu lieu en haute Mésopotamie?, Institut Français d'études anatoliennes Georges-Dumézil, Istanbul.

Laneri, N., Schwartz, M., D'Agostino, A., Valentini, S. and Pappalardo, G. (2006). A preliminary report of the archaeological excavations at Hirbemerdon Tepe, southeastern Turkey. Anatolica 32: 153-188. 
Lawler, A. (2006). North Versus south, Mesopotamian style. Science 312: 1458-1463.

Lebeau, M. (1997). La situation géographique, la topographie et les périodes d'occupation de Tell Beydar. In Lebeau, M. and Suleiman, A. (eds.), Tell Beydar, Three Seasons of Excavations (1992-1994): A Preliminary Report, Brepols, Turnhout, pp. 7-19.

Lebeau, M. (2000). Stratified archaeological evidence and compared periodizations in the Syrian Jezirah during the third millennium BC. In Marro, C. and Hauptmann, H. (eds.), Chronologies des pays du Caucase et de l'Euphrate aux IVe-IIIe millenaires, Institut Français d'Etudes Anatoliennes d'Istanbul, Paris, pp. 167-192.

Lebeau, M. (2006). Les temples de Tell Beydar et leur environnement immédiat à l'Époque Early Jezirah IIIb. In Butterlin, P., Lebeau, M., Monchambert, J.-Y., Montero Fenollós, J. L. and Muller, B. (eds.), Dimensions de l'expérience humaine au Proche-Orient ancien: volume d'hommage offert à Jean-Claude Margueron, Brepols, Turnhout, pp. 101-140.

Lebeau, M. and Suleiman, A. (eds.) (2003). Tell Beydar, the 1995-1999 Seasons of Excavations. A Preliminary Report, Brepols, Turnhout.

Lebeau, M. and Suleiman, A. (eds.) (2007). Tell Beydar: The 2000-2002 Seasons of Excavation; the 2003-2004 Seasons of Architectural Restoration. A Preliminary Report, Brepols, Turnhout.

Liverani, M. (2006). Uruk: The First City, Equinox, London and Oakville.

Lupton, A. (1996). Stability and Change: Socio-Political Development in North Mesopotamia and South-East Anatolia 4000-2700 BC, British Archaeological Reports, Oxford.

Lyonnet, B. (1998). Le peuplement de la Djéziré occidentale au début du 3e millénaire, villes circulaires et pastoralisme: questions et hypothèses. In Lebeau, M. (ed.) About Subartu: Studies Devoted to Upper Mesopotamia, Brepols, Turnhout, pp. 179-193. 
Lyonnet, B. (2007a). Introduction. In Lyonnet, B. (ed.) Les cultures du Caucase (VIe-IIIe millénaires avant notre ère): Leur relations avec le Proche-Orient, Éditions Recherche sur les Civilisations, Paris, pp. 11-19.

Lyonnet, B. (ed.) (2007b). Les cultures du Caucase (VIe-IIIe millénaires avant notre ère): Leur relations avec le Proche-Orient, Éditions Recherche sur les Civilisations, Paris.

Mallowan, M. E. L. (1947). Excavations at Brak and Chagar Bazar. Iraq 9: 1-257.

Margueron, J.-C. (2004). Mari: Métropole de l'Euphrate, Picard, Paris.

Marro, C. (2007). Upper-Mesopotamia and Transcaucasia in the late chalcolithic period (40003500 BC). In Lyonnet, B. (ed.) Les cultures du Caucase (VIe-IIIe millénaires avant notre ère): Leur relations avec le Proche-Orient, Éditions Recherche sur les Civilisations, Paris, pp. 77-94.

Marro, C. and Kuzucuoğlu, C. (2007). Northern Syria and upper Mesopotamia at the end of the third millennium BC: Did a crisis take place? In Kuzucuoğlu, C. and Marro, C. (eds.), Sociétés humaines et changement climatique à la fin du troisième millénaire: une crise at-elle eu lieu en haute Mésopotamie?, Institut Français d'études anatoliennes GeorgesDumézil, Istanbul, pp. 583-590.

Martin, L. (1998). Rettungsgrabungen im Gebiet des nördlichen Haburstausees. In Lebeau, M. (ed.) About Subartu: Studies Devoted to Upper Mesopotamia, Brepols, Turnhout, pp. $171-177$.

Matney, T. and Algaze, G. (1995). Urban development at mid-late early bronze age Titriş Höyük in southeastern Anatolia. Bulletin of the American Schools of Oriental Research 299/300: $33-52$. 
Matthews, R. (2002). Seven shrines of Subartu. In al-Gailani Werr, L., Curtis, J., Martin, H., McMahon, A., Oates, J. and Reade, J. (eds.), Of Pots and Plans: Papers on the Archaeology and History of Mesopotamia and Syria Presented to David Oates in Honour of his 75th Birthday, Nabu, London, pp. 186-190.

Matthews, R. (2003a). A chiefdom on the northern plains. Early third-millennium investigations: The Ninevite 5 period. In Matthews, R. (ed.) Excavations at Tell Brak Vol. 4: Exploring an Upper Mesopotamian Regional Centre, 1994-1996, McDonald Institute and British School of Archaeology in Iraq, Cambridge and London, pp. 97-191.

Matthews, W. (2003b). Microstratigraphic sequences: Indications of uses and concepts of space. In Matthews, R. (ed.) Excavations at Tell Brak Vol. 4: Exploring an Upper Mesopotamian Regional Centre, 1994-1996, McDonald Institute and British School of Archaeology in Iraq, Cambridge and London, pp. 377-388.

Matthews, W., French, C. A. I., Lawrence, T., Cutler, D. F. and Jones, M. K. (2001). Microstratigraphic analysis of depositional sequences in Areas FS and SS. In Oates, D., Oates, J. and McDonald, H., Excavations at Tell Brak, Vol. 2: Nagar in the Third Millennium BC. McDonald Institute for Archaeological Research and the British School of Archaeology in Iraq, Cambridge and London, pp. 353-367.

Mazzoni, S. (2003). Ebla: Crafts and power in an emergent state of third millennium BC Syria. Journal of Mediterranean Archaeology 16: 173-191.

McClellan, T. L. (1998). Tell Banat North: The White Monument. In Lebeau, M. (ed.) About Subartu: Studies Devoted to Upper Mesopotamia, Brepols, Turnhout, pp. 243-269. McClellan, T. L., Grayson, R. and Ogleby, C. (2000). Bronze age water harvesting in north Syria. In Rouault, O. and Wäfler, M. (eds.), La Djéziré et l'Euphrate Syriens de la 
protohistoire à la fin du IIe millénaire av. J.-C.: Tendances dans l'interprétation

historique des donnés nouvelles, Brepols, Turnhout, pp. 137-155.

McMahon, A. (1998). The Kuyunjik gully sounding, Nineveh, 1989 \& 1990 seasons. Al-Rafidan 19: $1-32$.

McMahon, A. (2006). The Early Dynastic To Akkadian Transition: The Area WF Sounding At Nippur, Oriental Institute of the University of Chicago, Chicago.

McMahon, A. and Oates, J. (2007). Excavations at Tell Brak 2006-2007. Iraq 69: 145-171.

Meyer, J.-W. (2006). Zur Chronologie von Tell Chuera. Baghdader Mitteilungen 37: 329-335.

Meyer, J.-W. (2007). Town Planning in 3rd Millennium Tell Chuera. In Bretschneider, J., Driessen, J. and van Lerberghe, K. (eds.), Power and Architecture: Monumental Public Architecture in the Bronze Age Near East and Aegean, Peeters, Leuven, pp. 129-142.

Michalowski, P. (1985). Third millennium contacts: Observations on the relationships between Mari and Ebla. Journal of the American Oriental Society 105: 293-302.

Miglus, P. A. and Strommenger, E. (2007). Ausgrabungen in Tall Bi'a/Tuttul VII: Der Palast A, Harrassowitz Verlag, Wiesbaden.

Monchambert, J.-Y. (1984). Le futur lac du Moyen Khabour: Rapport sur la prospection archéologique menée en 1983. Syria 61: 181-218.

Munchaev, R. M. and Merpert, N. Y. (2002). Twenty-five field seasons of the Russian mission in northern Mesopotamia. In al-Gailani Werr, L., Curtis, J., Martin, H., McMahon, A. and Reade, J. (eds.), Of Pots and Plans: Papers on the Archaeology and History of Mesopotamia and Syria Presented to David Oates in Honour of his 75th Birthday, Nabu Publications, London, pp. 240-258. 
Nissen, H. J. (2002). Uruk: Key site of the period and key site of the problem. In Postgate, J. N. (ed.) Artefacts of Complexity: Tracking the Uruk in the Near East, British School of Archaeology in Iraq, Warminster, pp. 1-16.

Oates, D. and Oates, J. (1991). Excavations at Tell Brak 1990-91. Iraq 53: 127-145.

Oates, D. and Oates, J. (1993). Excavations at Tell Brak 1992-93. Iraq 55: 155-199.

Oates, D. and Oates, J. (2001a). Archaeological Reconstruction and Historical Commentary. In Oates, D., Oates, J. and McDonald, H., Excavations at Tell Brak, Vol. 2: Nagar in the Third Millennium BC. McDonald Institute for Archaeological Research and the British School of Archaeology in Iraq, Cambridge and London, pp. 379-396.

Oates, D. and Oates, J. (2001b). The Excavations. In Oates, D., Oates, J. and McDonald, H., Excavations at Tell Brak, Vol. 2: Nagar in the Third Millennium BC. McDonald Institute for Archaeological Research and the British School of Archaeology in Iraq, Cambridge and London, pp. 15-98.

Oates, D. and Oates, J. (2006). Tripartite buildings and early urban Tell Brak. In Butterlin, P., Lebeau, M., Monchambert, J.-Y., Montero Fenollós, J. L. and Muller, B. (eds.), Dimensions de l'expérience humaine au Proche-Orient ancien: volume d'hommage offert à Jean-Claude Margueron, Brepols, Turnhout, pp. 33-40.

Oates, D., Oates, J. and McDonald, H. (2001). Excavations at Tell Brak, Vol. 2: Nagar in the Third Millennium BC, McDonald Institute for Archaeological Research and the British School of Archaeology in Iraq, Cambridge and London.

Oates, J. (2001). The Third Millennium Pottery. In Oates, D., Oates, J. and McDonald, H., Excavations at Tell Brak, Vol. 2: Nagar in the Third Millennium BC. McDonald Institute 
for Archaeological Research and the British School of Archaeology in Iraq, Cambridge and London, pp. 151-194.

Oates, J. (2002). Tell Brak: The 4th millennium sequence and its implications. In Postgate, J. N. (ed.) Artefacts of Complexity: Tracking the Uruk in the Near East, British School of Archaeology in Iraq, Warminster, pp. 111-122.

Oates, J. (2005). Archaeology in Mesopotamia: Digging deeper at Tell Brak. Proceedings of the British Academy 131: 1-39.

Oates, J., McMahon, A., Karsgaard, P., al-Quntar, S. and Ur, J. (2007). Early Mesopotamian urbanism: A new view from the North. Antiquity 81: 585-600.

Oates, J. and Oates, D. (2001c). The Late Third Millennium in the Khabur. In Meyer, J.-W., Novák, M. and Pruß, A. (eds.), Beiträge zur vorderasiatischen Archäologie Winfried Orthmann gewidmet, Johann Wolfgang Goethe-Universität, Frankfurt am Main, pp. 386389.

Oates, J. and Oates, D. (2002). The reattribution of middle Uruk materials at Brak. In Ehrenberg, E. (ed.) Leaving No Stones Unturned: Essays on the Ancient Near East and Egypt in Honor of Donald P. Hansen, Eisenbrauns, Winona Lake, pp. 145-54.

Ökse, A. T. (2007). A 'high' terrace at Gre Virike to the north of Carchemish: Power of local rulers as founders? In Peltenburg, E. (ed.) Euphrates River Valley Settlement: The Carchemish Sector in the Third Millennium BC, Oxbow Books, Oxford, pp. 94-104.

Orthmann, W. and Pruß, A. (1995). Der Palast F. In Orthmann, W. (ed.) Ausgrabungen in Tell Chuera in Nordost-Syrien I: Vorbericht über die Grabungskampagnen 1986 bis 1992, Saarbrücker Druckerei und Verlag, Saarbrücken, pp. 121-172. 
Parker, B. J., Foster, C. P., Henecke, J., Hopwood, M., Hopwood, D., Creekmore, A., Demirergi, A. and Eppihimer, M. (2008). Preliminary report from the 2005-2006 field seasons at Kenan Tepe. Anatolica 34: 103-176.

Pearce, J. (2000). The late chalcolithic sequence at Hacinebi Tepe, Turkey. In Marro, C. and Hauptmann, H. (eds.), Chronologies des pays du Caucase et de l'Euphrate aux IVe-IIIe millenaires, Institut Français d'Etudes Anatoliennes d'Istanbul, Paris, pp. 115-143.

Peltenburg, E. (1999a). The Living and the Ancestors: Early Bronze Age Mortuary Practices at Jerablus Tahtani. In del Olmo Lete, G. and Montero Fenollós, J.-L. (eds.), Archaeology of the Upper Syrian Euphrates: The Tishrin Dam Area, Editorial Ausa, Barcelona, pp. 427442.

Peltenburg, E. (1999b). Tell Jerablus Tahtani 1992-1996: A Summary. In del Olmo Lete, G. and Montero Fenollós, J.-L. (eds.), Archaeology of the Upper Syrian Euphrates: The Tishrin Dam Area, Editorial Ausa, Barcelona, pp. 97-105.

Peltenburg, E. (ed.) (2007a). Euphrates River Valley Settlement: The Carchemish Sector in the Third Millennium BC, Oxbow Books, Oxford.

Peltenburg, E. (2007b). New Perspectives on the Carchemish Sector of the Middle Euphrates River Valley in the 3rd Millennium BC. In Peltenburg, E. (ed.) Euphrates River Valley Settlement: The Carchemish Sector in the Third Millennium BC, Oxbow Books, Oxford, pp. 3-24.

Pfälzner, P. (1997). Wandel und Kontinuität im Urbanisierungsprocess des 3. Jtsds. in Nordmesopotamien. In Wilhelm, G. (ed.) Die orientalische Stadt: Kontinuität, Wandel, Bruch, Saarbrücken, pp. 239-265. 
Pfälzner, P. (1998). Eine Modifikation der Periodisierung Nordmesopotamiens im 3. Jtsd. v. Chr. Mitteilungen der Deutschen Orient-Gesellschaft zu Berlin 130: 69-71.

Pfälzner, P. (2001). Haus und Haushalt: Wohnformen des dritten Jahrtausends vor Christus in Nordmespotamien, Philipp von Zabern, Mainz am Rhein.

Pfälzner, P. (2002). Modes of storage and the development of economic systems in the Early Jezireh period. In al-Gailani Werr, L., Curtis, J., Martin, H., McMahon, A., Oates, J. and Reade, J. (eds.), Of Pots and Plans: Papers on the Archaeology and History of Mesopotamia and Syria Presented to David Oates in Honour of his 75th Birthday, Nabu, London, pp. 259-286.

Pfälzner, P., Wissing, A. and Hubner, C. (2004). Urbanismus in der Unterstadt von Urkeš: Ergebnisse einer geomagnetischen Prospektion und eines archaologischen Surveys in der sudostlichen Unterstadt von Tall Mozan im Sommer 2002. Mitteilungen der Deutschen Orient-Gesellschaft zu Berlin 136: 41-86.

Pittman, H. (1999). Administrative evidence from Hacinebi Tepe: An essay on the global and the local. Paléorient 25: 43-50.

Pollock, S. (1999). Ancient Mesopotamia: The Eden the Never Was, Cambridge University Press, Cambridge.

Porter, A. (2002). The dynamics of death: Ancestors, pastoralism, and the origins of a thirdmillennium city in Syria. Bulletin of the American Schools of Oriental Research 325: 136.

Porter, A. (2004). The urban nomad: Countering the old clichés. In Nicolle, C. (ed.) Nomades et sédentaires dans le Proche-Orient ancien, Editions Recherche sur les civilisations, Paris, pp. 69-74. 
Postgate, J. N. (ed.) (2002). Artefacts of Complexity: Tracking the Uruk in the Near East, British School of Archaeology in Iraq, Warminster.

Rainville, L. (2005). Investigating Upper Mesopotamian Households Using MicroArchaeological Techniques, Archaeopress, Oxford.

Reade, J. (1997). Taya, Tell. In Meyers, E. (ed.) The Oxford Encylopedia of Archaeology in the Ancient Near East, Oxford University Press, New York and Oxford, pp. 158-160.

Reichel, C. (2002). Administrative complexity in Syria during the 4th millennium BC: The seals and sealings from Tell Hamoukar. Akkadica 123: 35-56.

Renger, J. (2003). Oikos, Oikoswirtschaft. Reallexikon der Assyriologie und vorderasiatischen Archäologie 10: 43-45.

Renger, J. M. (1995). Institutional, communal, and individual ownership or possession of arable land in ancient Mesopotamia from the end of the fourth to the end of the first Millennium BC. Chicago-Kent Law Review 71: 269-319.

Rothman, M. S. (2001a). The local and the regional: An introduction. In Rothman, M. (ed.) Uruk Mesopotamia \& its Neighbors: Cross-Cultural Interactions in the Era of State Formation, School of American Research Press, Santa Fe and Oxford, pp. 3-26.

Rothman, M. S. (2001b). The Tigris piedmont, eastern Jazira, and highland western Iran in the fourth millennium BC. In Rothman, M. (ed.) Uruk Mesopotamia \& its Neighbors: CrossCultural Interactions in the Era of State Formation, School of American Research Press, Santa Fe and Oxford, pp. 349-401.

Rothman, M. S. (ed.) (2001c). Uruk Mesopotamia \& its Neighbors: Cross-Cultural Interactions in the Era of State Formation, School of American Research, Santa Fe. 
Rothman, M. S. (2002a). Tepe Gawra: Chronology and socio-economic change in the foothills of northern Iraq in the era of state formation. In Postgate, J. N. (ed.) Artefacts of Complexity: Tracking the Uruk in the Near East, British School of Archaeology in Iraq, Warminster, pp. 49-77.

Rothman, M. S. (2002b). Tepe Gawra: The Evolution of a Small, Prehistoric Center in Northern Iraq, University of Pennsylvania Museum of Archaeology and Anthropology, Philadelphia.

Rothman, M. S. (2004). Studying the development of complex society: Mesopotamia in the late fifth and fourth millennia BC. Journal of Archaeological Research 12: 75-119.

Rothman, M. S. and Blackman, M. J. (2003). Late fifth and early fourth millennium exchange systems in northern Mesopotamia: Chemical characterization of sprig and impressed wares. Al-Rafidain 24: 1-24.

Rothman, M. S. and Peasnall, B. (1999). Societal evolution of small, pre-state centers and polities: The example of Tepe Gawra in northern Mesopotamia Paléorient 25: 101-114.

Rova, E. (1996). Ceramic provinces along the middle and upper Euphrates: Late chalcolithicearly bronze age, a diachronic view. Baghdader Mitteilungen 27: 13-37.

Rova, E. (2000). Early third millennium BC painted pottery traditions in the Jezirah. In Marro, C. and Hauptmann, H. (eds.), Chronologies des pays du Caucase et de l'Euphrate aux IVe-IIIe millenaires, Institut Français d'Etudes Anatoliennes d'Istanbul, Paris, pp. 231254.

Rova, E. (2003). The III Millennium pottery morphology: The typology principles, the coding system and some preliminary results. In Lebeau, M. and Suleiman, A. (eds.), Tell Beydar, 
the 1995-1999 Seasons of Excavations. A Preliminary Report, Brepols, Turnhout, pp. 395-489.

Schloen, J. D. (2001). The House of the Father as Fact and Symbol: Patrimonialism in Ugarit and the Ancient Near East, Eisenbrauns, Winona Lake.

Schwartz, G. (1994a). Before Ebla: Models of pre-state political organization in Syria and northern Mesopotamia. In Stein, G. and Rothman, M. (eds.), Chiefdoms and Early States in the Near East: The Organizational Dynamics of Complexity, Prehistory Press, Madison, pp. 153-174.

Schwartz, G. (1994b). Rural economic specialization and early urbanization in the Khabur valley, Syria. In Schwartz, G. and Falconer, S. (eds.), Archaeological Views from the Countryside: Village Communities in Early Complex Societies, Smithsonian Institution Press, Washington, DC, pp. 19-36.

Schwartz, G. (2000). Perspectives on rural ideologies: The Tell al-Raqa'i temple. In Rouault, O. and Wäfler, M. (eds.), La Djéziré et l'Euphrate Syriens de la protohistoire à la fin du IIe millénaire av. J.-C.: Tendances dans l'interprétation historique des donnés nouvelles, Brepols, pp. 163-182.

Schwartz, G. (2001). Syria and the Uruk expansion. In Rothman, M. (ed.) Uruk Mesopotamia \& its Neighbors: Cross-Cultural Interactions in the Era of State Formation, School of American Research Press, Santa Fe and Oxford, pp. 233-264.

Schwartz, G. and Curvers, H. (1992). Tell al-Raqa'i 1989 and 1990: Further investigations at a small rural site of early urban northern Mesopotamia. American Journal of Archaeology 96: 397-419. 
Schwartz, G. M. (2007). Taking the Long View on Collapse: A Syrian Perspective. In Kuzucuoğlu, C. and Marro, C. (eds.), Sociétés humaines et changement climatique à la fin du troisième millénaire: une crise a-t-elle eu lieu en haute Mésopotamie?, Institut Français d'études anatoliennes Georges-Dumézil, Istanbul, pp. 45-67.

Schwartz, G. M., Curvers, H. H., Dunham, S., Stuart, B. and Weber, J. (2006). A third millennium B.C. elite mortuary complex at Umm el-Marra, Syria: 2002-2004 excavations. American Journal of Archaeology 110: 603-641.

Schwartz, G. M. and Klucas, E. E. (1998). Spatial analysis and social structure at Tell al-Raqa'i. In Fortin, M. and Aurenche, O. (eds.), Espace naturel, espace habit en Syrie du Nord (10e-2e millenaires av. J.-C.), Canadian Society for Mesopotamian Studies and Maison de l'Orient Mediterranean, Quebec and Lyon, pp. 199-207.

Senior, L. and Weiss, H. (1992). Tell Leilan 'sila bowls' and the Akkadian re-organization of Subarian agricultural production. Orient-Express 1992: 1-6.

Senior, L. M. (1998). Time and Technological Change: Ceramic Production, Labor, and Economic Transformation in a Third Millennium Complex Society (Tell Leilan, Syria), Ph.D dissertation, Department of Anthropology, University of Arizona, Tucson, AZ. Sołtysiak, A. (2007). Preliminary Report on the Human Remains from Tell Majnuna (Spring 2007). Iraq 69: 161-163.

Staubwasser, M. and Weiss, H. (2006). Holocene climate and cultural evolution in late prehistoric-early historic west Asia. Quaternary Research 66: 372-387.

Stein, G. (1994). Segmentary states and organizational variation in early complex societies. In Schwartz, G. and Falconer, S. (eds.), Archaeological Views from the Countryside: Village 
Communities in Early Complex Societies, Smithsonian Institution Press, Washington, DC, pp. 10-18.

Stein, G. J. (1999). Rethinking World-Systems: Diasporas, Colonies, and Interaction in Uruk Mesopotamia, University of Arizona Press, Tucson.

Stein, G. J. (2004). Structural parameters and sociocultural factors in the economic organization of north Mesopotamian urbanism in the third millennium BC. In Feinman, G. M. and Nicholas, L. M. (eds.), Archaeological Perspectives on Political Economies, University of Utah Press, Salt Lake City, pp. 61-78.

Stein, G. J. and Blackman, M. J. (1993). The organizational context of specialized craft production in early Mesopotamian states. Research in Economic Anthropology 14: 29-59.

Stein, G. J. and Özbal, R. (2007). A Tale of Two Oikumenai: Variation in the Expansionary Dynamics of 'Ubaid and Uruk Mesopotamia. In Stone, E. C. (ed.) Settlement and Society: Essays Dedicated to Robert McCormick Adams, Cotsen Institute of Archaeology, Los Angeles, pp. 329-342.

Stein, G. J. and Wattenmaker, P. (2003). Settlement trends and the emergence of social complexity in the Leilan region of the Habur plains (Syria) from the fourth to the third millennium BC. In Rova, E. and Weiss, H. (eds.), The Origins of North Mesopotamian Civilization: Ninevite 5 Chronology, Economy, Society, Brepols, Turnhout, pp. 361-386.

Steinkeller, P. (2007). City and countryside in third-millennium southern Babylonian. In Stone, E. C. (ed.) Settlement and Society: Essays Dedicated to Robert McCormick Adams, Cotsen Institute of Archaeology, Los Angeles, pp. 185-211.

Thuesen, I. (2000). Ubaid Expansion in the Khabur: New Evidence from Tell Mashnaqa. In Rouault, O. and Wäfler, M. (eds.), La Djéziré et l'Euphrate Syriens de la protohistoire à 
la fin du IIe millénaire av. J.-C.: Tendances dans l'interprétation historique des donnés nouvelles, Brepols, Turnhout, pp. 71-79.

Tomita, T. (1998). Late chalcolithic chronology in Syria and northern Mesopotamia. In Tsuneki, A. and Miyake, Y. (eds.), Excavations at Tell Umm Qseir in Middle Khabur Valley North Syria: Report of the 1996 Season, Dept. of Archaeology, University of Tsukuba, Tsukuba, pp. 197-201.

Tunca, Ö., McMahon, A. and Baghdo, A.-M. (eds.) (2007). Chagar Bazar (Syrie) II. Les vestiges post-akkadiens du chantier D et études diverses, Peeters, Leuven.

Ur, J. A. (2002a). Settlement and landscape in northern Mesopotamia: The Tell Hamoukar survey 2000-2001. Akkadica 123: 57-88.

Ur, J. A. (2002b). Surface collection and offsite studies at Tell Hamoukar, 1999. Iraq 64: 15-44.

Ur, J. A. (2003). CORONA satellite photography and ancient road networks: A northern Mesopotamian case study. Antiquity 77: 102-115.

Ur, J. A. (2004). Urbanism and Society in the Third Millennium Upper Khabur Basin, Ph.D. dissertation, Department of Near Eastern Languages and Civilizations, University of Chicago, Chicago, IL.

Ur, J. A. (2009). Emergent landscapes of movement in early bronze age northern Mesopotamia. In Snead, J. E., Erickson, C. and Darling, W. A. (eds.), Landscapes of Movement: Paths, Trails, and Roads in Anthropological Perspective, University of Pennsylvania Museum Press, Philadelphia, pp. 180-203.

Ur, J. A. (in press-a). Urban Form at Tell Brak Across Three Millennia. In Crawford, H., McMahon, A. and Postgate, J. N. (eds.), Preludes to Urbanism: Studies in the Late 
Chalcolithic of Mesopotamia in Honour of Joan Oates, McDonald Institute for Archaeological Research, Cambridge.

Ur, J. A. (in press-b). Urbanism and Cultural Landscapes in Northeastern Syria: The Tell Hamoukar Survey, 1999-2001, University of Chicago Oriental Institute, Chicago.

Ur, J. A. and Colantoni, C. (in press). The Cycle of Production, Preparation, and Consumption in a Northern Mesopotamian City. In Klarich, E. (ed.) From Subsistence to Social Strategies: New Directions in the Study of Daily Meals and Feasting Events, University of Colorado Press, Boulder.

Ur, J. A., Karsgaard, P. and Oates, J. (2007). Urban development in the ancient Near East. Science 317: 1188.

Ur, J. A. and Wilkinson, T. J. (2008). Settlement and economic landscapes of Tell Beydar and its hinterland. In Lebeau, M. and Suleiman, A. (eds.), Beydar Studies I, Brepols, Turnhout, pp. 305-327.

Vallet, R. (1996). Habuba Kebira, ou la naissance de l'urbanisme. Paléorient 22: 45-76.

Vallet, R. (1998). L'urbanisme colonial urukien: l'exemple de Djebel Aruda. In Lebeau, M. (ed.) About Subartu: Studies Devoted to Upper Mesopotamia Vol. 1: Landscape, Archaeology, Settlement, Brepols, Turnhout, pp. 53-87.

van Driel, G. (2002). Jebel Aruda: Variations on a late Uruk domestic theme. In Postgate, J. N. (ed.) Artefacts of Complexity: Tracking the Uruk in the Near East, British School of Archaeology in Iraq, Warminster, pp. 191-205.

Van Loon, M. N. (ed.) (1988). Hammam et-Turkman I, Nederlands Historisch-Archaeologisch Instituut, Istanbul. 
Wattenmaker, P. (1998). Household and State in Upper Mesopotamia: Specialized Economy and the Social Uses of Goods in an Early Complex Society, Smithsonian Institution Press, Washington and London.

Weber, J. (2001). A preliminary assessment of Akkadian and post-Akkadian animal exploitation at Tell Brak. In Oates, D., Oates, J. and McDonald, H., Excavations at Tell Brak, Vol. 2: Nagar in the Third Millennium BC. McDonald Institute for Archaeological Research and the British School of Archaeology in Iraq, Cambridge and London, pp. 345-350.

Weber, J. (2007). Community and household: A preliminary report on the animal remains from the excavations at Tell Brak, 2007. Iraq 69: 167-170.

Weber, J. (2008). Elite equids: Redefining equid burials of the late 3rd millennium BC from Umm El-Marra (Syria). In Vila, E., Gourichon, L., Choyke, A. and Buitenhuis, H. (eds.), Archaeozoology of the Southwest Asia and Adjacent Areas VIII, Maison de l'Orient méditerranéen, Lyon, pp. 499-519.

Weiss, H. (1990). Tell Leilan 1989: New data for mid-third millennium urbanization and state formation. Mitteilungen der Deutschen Orient-Gesellschaft zu Berlin 122: 193-218.

Weiss, H. (1992). Habur triangles: Third millennium urban settlement in Subir. N.A.B.U. 1992: 91-94.

Weiss, H. (1997). Leilan, Tell. In Meyers, E. (ed.) The Oxford Encylopedia of Archaeology in the Ancient Near East, Oxford University Press, New York and Oxford, pp. 341-347.

Weiss, H. (2000). Causality and chance: Late third millennium collapse in southwest Asia. In Rouault, O. and Wäfler, M. (eds.), La Djéziré et l'Euphrate Syriens de la protohistoire à la fin du IIe millénaire av. J.-C.: Tendances dans l'interprétation historique des donnés nouvelles, Brepols, Turnhout, pp. 207-217. 
Weiss, H. (2003). Ninevite 5 periods and processes. In Rova, E. and Weiss, H. (eds.), The Origins of North Mesopotamian Civilization: Ninevite 5 Chronology, Economy, Society, Brepols, Turnhout, pp. 593-624.

Weiss, H. and Courty, M.-A. (1993). The genesis and collapse of the Akkadian empire: The accidental refraction of historical law. In Liverani, M. (ed.) Akkad: The First World Empire, Sargon, Padova, pp. 131-155.

Weiss, H., Courty, M.-A., Wetterstrom, W., Guichard, F., Senior, L., Meadow, R. and Curnow, A. (1993). The genesis and collapse of third millennium north Mesopotamian civilization. Science 261: 995-1004.

Westenholz, A. (1999). The Old Akkadian period: History and culture. Mesopotamien: AkkadeZeit und Ur III-Zeit, Universitätsverlag Freiburg and Vandenhoeck \& Ruprecht, Freiburg and Göttingen, pp. 17-117.

Wilkinson, T. J. (1993). Linear hollows in the Jazira, upper Mesopotamia. Antiquity 67: 548-562.

Wilkinson, T. J. (1994). The structure and dynamics of dry-farming states in upper Mesopotamia. Current Anthropology 35: 483-520.

Wilkinson, T. J. (1997). Environmental fluctuations, agricultural production and collapse: A view from bronze age upper Mesopotamia. In Dalfes, H. N., Kukla, G. and Weiss, H. (eds.), Third Millennium BC Climate Change and Old World Collapse, Springer-Verlag, Berlin and Heidelberg, pp. 67-106.

Wilkinson, T. J. (2000a). Regional approaches to Mesopotamian archaeology: The contribution of archaeological surveys. Journal of Archaeological Research 8: 219-267. 
Wilkinson, T. J. (2000b). Settlement and land use in the zone of uncertainty in upper Mesopotamia. In Jas, R. M. (ed.) Rainfall and Agriculture in Northern Mesopotamia, Nederlands Historisch-Archaeologisch Instituut te Istanbul, Istanbul, pp. 3-35.

Wilkinson, T. J. (2002). Physical and cultural landscapes of the Hamoukar area. Akkadica 123: 89-105.

Wilkinson, T. J. (2003). Archaeological Landscapes of the Near East, University of Arizona Press, Tucson.

Wilkinson, T. J. (2004). On the Margin of the Euphrates: Settlement and Land Use at Tell esSweyhat and in the Upper Lake Assad Area, Syria, Oriental Institute, Chicago.

Wilkinson, T. J., Christiansen, J., Ur, J. A., Widell, M. and Altaweel, M. (2007a). Urbanization within a dynamic environment: Modelling bronze age communities in upper Mesopotamia. American Anthropologist 109: 52-68.

Wilkinson, T. J., Gibson, M., Christiansen, J., Widell, M., Schloen, D., Kouchoukos, N., Woods, C., Sanders, J. C., Simunich, K.-L., Altaweel, M., Ur, J. A., Hritz, C., Lauinger, J., Paulette, T. and Tenney, J. (2007b). Modeling settlement systems in a dynamic environment: Case studies from Mesopotamia. In Kohler, T. A. and van der Leeuw, S. (eds.), The Model-Based Archaeology of Socionatural Systems, School of American Research, Santa Fe, pp. 175-208.

Wilkinson, T. J., Peltenburg, E., McCarthy, A., Wilkinson, E. and Brown, M. (2007c). Archaeology in the land of Carchemish: Landscape surveys in the area of Jerablus Tahtani, 2006. Levant 39: 213-247.

Wilkinson, T. J. and Tucker, D. J. (1995). Settlement Development in the North Jazira, Iraq, Aris \& Phillips, Ltd, Warminster. 
Wright, H. T. (2007). Ancient agency: Using models of intentionality to understand the dawn of despotism. In Stone, E. C. (ed.) Settlement and Society: Essays Dedicated to Robert McCormick Adams, Cotsen Institute of Archaeology, Los Angeles, pp. 173-184.

Wright, H. T. and Rupley, E. S. A. (2001). Calibrated radiocarbon age determinations of Urukrelated assemblages. In Rothman, M. (ed.) Uruk Mesopotamia \& its Neighbors: CrossCultural Interactions in the Era of State Formation, School of American Research Press, Santa Fe and Oxford, pp. 85-122.

Yoffee, N. (2005). Myths of the Archaic State: Evolution of the Earliest Cities, States, and Civilizations, Cambridge University Press, Cambridge.

Zeder, M. A. (1998). Environment, economy, and subsistence on the threshold of urban emergence in northern Mesopotamia. In Fortin, M. and Aurenche, O. (eds.), Natural Space, Inhabited Space in Northern Syria (10th-2nd Millennium BC), Canadian Society for Mesopotamian Studies, Quebec, pp. 55-67.

Zeder, M. A. (2003). Food provisioning in urban societies: A view from northern Mesopotamia. In Smith, M. L. (ed.) The Social Construction of Ancient Cities, Smithsonian Institution, Washington and London, pp. 156-183.

Zettler, R. L. (ed.) (1997). Subsistence and Settlement in a Marginal Environment: Tell esSweyhat, 1989-1995 Preliminary Report, University of Pennsylvania Museum of Archaeology and Anthropology, Philadelphia. 


\section{Bibliography}

Algaze, G., Kelly, J., Matney, T. and Schlee, D. (1996). Late EBA urban structure at Titriş Höyük, southeastern Turkey: The 1995 season. Anatolica 22: 129-143.

Algaze, G. and Pournelle, J. (2003). Climatic change, environmental change, and social change at early bronze age Titriş Höyük. In Özdoğan, M., Hauptmann, H. and Başgelen, N. (eds.), From Villages to Towns: Studies Presented to Ufuk Esin, Arkeoloji ve Sanat Publications, Istanbul.

al-Maqdissi, M., Matoiän, V. and Nicolle, C. (eds.) (2007). La céramique du l'âge du Bronze en Syrie II: L'Euphrate et la région de Jézireh, IFAPO, Damascus.

Altaweel, M. (2008). Investigating agricultural sustainability and strategies in northern Mesopotamia: Results produced using a socio-ecological model. Journal of Archaeological Science 35: 821-835.

Bachmann, F. (1998). Das keramische Inventar eines urukzeitlichen Gabäudes in Tell Sheikh Hassan / Syrien. In Lebeau, M. (ed.) About Subartu: Studies Devoted to Upper Mesopotamia, Brepols, Turnhout, pp. 89-129.

Behm-Blancke, M. R. (2003). Northern frontiers: Early Ninevite 5 contacts with southeastern Anatolia. In Rova, E. and Weiss, H. (eds.), The Origins of North Mesopotamian Civilization: Ninevite 5 Chronology, Economy, Society, Brepols, Turnhout, pp. 481-492.

Bernbeck, R. (1993). Steppe als Kulturlandschaft, Dietrich Reimer Verlag, Berlin. Blackburn, M. and Fortin, M. (1994). Geomorphology of Tell 'Atij, northern Syria. Geoarchaeology 9: 58-73. 
Blackman, M. J., Stein, G. J. and Vandiver, P. (1993). The standardization hypothesis and ceramic mass production: Technological, compositional, and metric indexes of craft specialization at Tell Leilan, Syria. American Antiquity 58: 60-80.

Boese, J. (1995). Ausgrabungen in Tell Sheikh Hassan I: Vorläufige Berichte über die Ausgrabungskampagnen 1984-1990 und 1992-1994, Saarbrücken Druckerei und Verlag, Saarbrücken.

Bottema, S. (1997). Third millennium climate in the Near East based on pollen evidence. In Dalfes, H. N., Kukla, G. and Weiss, H. (eds.), Third Millennium BC Climate Change and Old World Collapse, Springer Verlag, Berlin, pp. 489-515.

Bretschneider, J. and Jans, G. (1997). Palast und Verwaltung: Synchronismen im Haburgebiet im 3. Jahrtausend v. Chr. Ugarit-Forschungen 29: 67-93.

Brustolon, A. and Rova, E. (2007). The late chalcolithic period in the Tell Leilan region: A report on the ceramic material of the 1995 survey. Kaskal 4: 1-42.

Buccellati, G. and Kelly-Buccellati, M. (1995/96). The royal storehouse of Urkesh: The glyptic evidence from the southwestern wing. Archiv für Orientforschung 42/43: 1-32.

Bunnens, G. (2007). Site hierarchy in the Tishrin dam area and third millennium geopolitics in northern Syria. In Peltenburg, E. (ed.) Euphrates River Valley Settlement: The Carchemish Sector in the Third Millennium BC, Oxbow, Oxford, pp. 43-54.

Castel, C. (2007). L'abandon d'al-Rawda (Syrie) à la fin du troisième millénaire: premières tentatives d'explication. In Kuzucuoğlu, C. and Marro, C. (eds.), Sociétés humaines et changement climatique à la fin du troisième millénaire: une crise a-t-elle eu lieu en haute Mésopotamie?, Institut Français d'études anatoliennes Georges-Dumézil, Istanbul, pp. $159-178$. 
Cooper, L. (2006). The demise and regeneration of bronze age urban centers in the Euphrates valley of Syria. In Schwartz, G. and Nichols, J. J. (eds.), After Collapse: The Regeneration of Complex Societies, University of Arizona, Tucson, pp. 18-37.

Courty, M. A. (1994). Le cadre paléographique des occupations humaines dans le bassin du Haut-Khabur (Syrie du Nord-Est). Premiers résultats. Paléorient 20: 21-59.

Cullen, H. M., de Menocal, P. B., Hemming, S., Hemming, G., Brown, F. H., Guilderson, T. and Sirocko, F. (2000). Climate change and the collapse of the Akkadian empire: Evidence from the deep sea. Geology 28: 379-382.

Curvers, H. H., Schwartz, G. M. and Dunham, S. (1997). Umm el-Marra, a bronze age urban center in the Jabbul plain, western Syria. American Journal of Archaeology 101: 201239.

Danti, M. and Zettler, R. L. (1998). The evolution of the Tell es-Sweyhat (Syria) settlement system in the third millennium B.C. In Fortin, M. and Aurenche, O. (eds.), Espace naturel, espace habit en Syrie du Nord (10e-2e millenaires av. J.-C.), Canadian Society for Mesopotamian Studies and Maison de l'Orient Mediterranian, Quebec and Lyon, pp. 209-228.

del Olmo Lete, G. (1994). Tell Qara Quzaq I. Campañas I-III (1989-1991), Barcelona.

Dohmann-Pfälzner, H. and Pfälzner, P. (1996). Untersuchung zur Urbanisierung Nordmesopotamiens im 3. Jt. v. Chr.: Wohnquartierplanung und städtische Zentrumsgestaltung in Tall Chuera. Damaszener Mitteilung 9: 1-13.

Eidem, J. and Warburton, D. (1996). In the land of Nagar: A survey around Tell Brak. Iraq 58: $51-64$. 
Forest, J.-D. (2003). The Ninevite 5 culture: Its nature and origins. In Rova, E. and Weiss, H. (eds.), The Origins of North Mesopotamian Civilization: Ninevite 5 Chronology, Economy, Society, Brepols, Turnhout, pp. 563-584.

Fortin, M. (2007). La céramique du Bronze ancien dan la Jézireh et la vallée du Khabur. In alMaqdissi, M., Matoiän, V. and Nicolle, C. (eds.), La céramique du l'âge du Bronze en Syrie II: L'Euphrate et la région de Jézireh, IFAPO, Damascus, pp. 155-178.

Frane, J. E. (1996). The Tell Leilan Period I Habur Ware Assemblage, Ph.D. dissertation, Department of Classics, University of North Carolina-Chapel Hill.

Geyer, B. (ed.) (2001). Conquête de la steppe et appropriation des terres sur les marges arides du Croissant fertile, Maison de l'Orient Méditerranéen-Jean Pouilloux, Lyon.

Gut, R. V., Reade, J. and Boehmer, R. M. (2001). Ninive-Das späte 3. Jahrtausend v. Chr. In Meyer, J.-W., Novák, M. and Pruß, A. (eds.), Beiträge zur vorderasiatischen Archäologie Winfried Orthmann gewidmet, Johann Wolfgang Goethe-Universität, Frankfurt am Main, pp. 74-129.

Hartenberger, B. (2003). A Study of Craft Specialization and the Organization of Chipped Stone Production at Early Bronze Age Titriş Höyük, Southeastern Turkey, Ph.D. dissertation, Department of Archaeology, Boston University, Boston.

Helwing, B. (2003). Feasts as a social dynamic in prehistoric western Asia: Three case studies from Syria and Anatolia. Paléorient 29: 63-86.

Hole, F. (1994). Environmental instabilities and urban origins. In Stein, G. and Rothman, M. (eds.), Chiefdoms and Early States in the Near East: The Organizational Dynamics of Complexity, Prehistory Press, Madison, pp. 121-151. 
Hole, F. (1998). Paleoenvironment and human society in the Jezireh of northern Mesopotamia 20,000-6,000 BP. Paléorient 23: 17-29.

Hole, F. (2002-2003). Khabur Basin Project, 1986-2001. Les annales archéologiques de Syrie 45-46: 11-20.

Holland, T. (2006). Excavations at Tell es-Sweyhat, Syria Volume 2: Archaeology of the Bronze Age, Hellenistic, and Roman Remains at an Ancient Town on the Euphrates River, Oriental Institute of the University of Chicago Chicago.

Kelly-Buccellati, M. (2002). Ein hurritischer Gang in die Unterwelt. Mitteilungen der Deutschen Orient-Gesellschaft zu Berlin 132: 131-148.

Kepinski, C. (2007). Dynamics, diagnostic criteria and settlement patterns in the Carchemish area during the early bronze period. In Peltenburg, E. (ed.) Euphrates River Valley Settlement: The Carchemish Sector in the Third Millennium BC, Oxbow, Oxford, pp. 152-163.

Klengel-Brandt, E., Kuleman-Ossen, S. and Martin, L. (2005). Tall Knedig: Die Ergebnisse der Ausgrabungen des vorderasiatischen Museums Berlin in Nordost-Syrien von 1993 bis 1998, Saarländische Druckerei \& Verlag, Saarwellingen.

Kolinski, R. (2007). Sir Max Mallowan's excavations at Tell Arbid in 1936. Iraq 69: 73-115. Kuzucuoğlu, C. (2007). Climatic and environmental trends during the third millennium BC in upper Mesopotamia. In Kuzucuoğlu, C. and Marro, C. (eds.), Sociétés humaines et changement climatique à la fin du troisième millénaire: une crise a-t-elle eu lieu en haute Mésopotamie?, Institut Français d'études anatoliennes Georges-Dumézil, Istanbul, pp. 459-480. 
Laneri, N. (2007). Burial practices at Titriş Höyük, Turkey: An interpretation. Journal of Near Eastern Studies 66: 241-266.

Laneri, N., Schwartz, M., Ur, J. A., Valentini, S., D'Agostino, A., Berthon, R. and Hald, M. M. (2008). The Hirbemerdon Tepe archaeological project 2006-2007: A preliminary report on the middle bronze age 'architectural complex' and the survey of the site catchment area. Anatolica 34: 177-240.

Lebeau, M. (ed.) (1998). About Subartu: Studies Devoted to Upper Mesopotamia, Brepols, Turnhout.

Lebeau, M. (2000). Les voies de communication en Haute Mésopotamie au IIIe millénaire avant notre ère. In Rouault, O. and Wäfler, M. (eds.), La Djéziré et l'Euphrate syriens de la protohistoire à la fin du Ile millénaire av. J.-C. : tendances dans l'interprétation historique des données nouvelles, Brepols, Turnhout, pp. 157-162.

Lebeau, M. and Suleiman, A. (eds.) (1997). Tell Beydar, Three Seasons of Excavations (19921994): A Preliminary Report, Brepols, Turnhout.

Lebeau, M. and Suleiman, A. (eds.) (2003). Tell Beydar, the 1995-1999 Seasons of Excavations. A Preliminary Report, Brepols, Turnhout.

Lebeau, M. and Suleiman, A. (eds.) (2007). Tell Beydar: The 2000-2002 Seasons of Excavation; the 2003-2004 Seasons of Architectural Restoration. A Preliminary Report, Brepols, Turnhout.

Lyonnet, B. (1996). La prospection archéologique de la partie occidentale du Haut-Khabur (Syrie du nord-est): Méthodes, résultats et questions autour de l'occupation aux IIIe et IIe millénaires Av. N. È. Amurru 1: 363-376. 
Lyonnet, B. (ed.) (2000). Prospection archéologique du Haut-Khabur occidental (Syrie du N.E.) Vol. I, Institut Français d'archéoloqie du proche-orient, Beirut.

Lyonnet, B. (2004). Le nomadisme et l'archéologie: problèmes d'identification. Le cas de la partie occidentale de la Djéziré aux 3ème et début du 2ème millénaire avant notre ère. In Nicolle, C. (ed.) Nomades et sédentaires dans le Proche-Orient ancien, Editions Recherche sur les civilisations, Paris, pp. 25-49.

Marro, C. (2007). Continuity and change in the Birecik valley at the end of the third millennium B.C: The archaeological evidence from Horum Höyük. In Kuzucuoğlu, C. and Marro, C. (eds.), Sociétés humaines et changement climatique à la fin du troisième millénaire: une crise a-t-elle eu lieu en haute Mésopotamie?, Institut Français d'études anatoliennes Georges-Dumézil, Istanbul, pp. 383-401.

Matthews, D. (1997). The Early Glyptic of Tell Brak, Universitätsverlag and Vandenhoeck \& Ruprecht, Fribourg and Göttingen.

Matthews, R. (ed.) (2003). Excavations at Tell Brak Vol. 4: Exploring an Upper Mesopotamian Regional Centre, 1994-1996, McDonald Institute, Cambridge.

Matthews, R. J. (1994). Imperial catastrophe or local incident? An Akkadian hoard from Tell Brak. Cambridge Archaeological Journal 4: 290-302.

Mazzoni, S. (2006). Syria and the emergence of cultural complexity. In Baffi, F., Dolce, R., Mazzoni, S. and Pinnock, F. (eds.), Ina kibret erbetti. Studi di Archeologia orientale dedicati a Paolo Matthiae, Università di Roma La Sapienza, Rome, pp. 321-347.

McClellan, T. L. (1999). Urbanism on the upper Syrian Euphrates. In del Olmo Lete, G. and Montero Fenollós, J.-L. (eds.), Archaeology of the Upper Syrian Euphrates: The Tishrin Dam Area, Editorial Ausa, Barcelona, pp. 413-425. 
McClellan, T. L. (2004). Funerary monuments and pastoralism. In Nicolle, C. (ed.) Nomades et sédentaires dans le Proche-Orient ancient: compte rendu de la XLVIe Rencontre assyriologique internationale, Editions Recherche sur les civilisations, Paris, pp. 63-67.

McCorriston, J. (1995). Preliminary archaeobotanical analysis in the middle Habur Valley, Syria and studies of socioeconomic change in the early third millennium B.C. Bulletin of the Canadian Society for Mesopotamian Studies 29: 33-46.

McCorriston, J. and Weisberg, S. (2002). Spatial and temporal variation in Mesopotamian agricultural practices in the Khabur basin, Syrian Jazira. Journal of Archaeological Science 29: 485-498.

Menze, B. H., Ur, J. A. and Sherratt, A. G. (2006). Detection of ancient settlement mounds: Archaeological survey based on the SRTM terrain model. Photogrammetric Engineering \& Remote Sensing 72: 321-327.

Meyer, J.-W. (1996). Offene und geschlossene Siedlungen. Altorientalische Forschungen 23: $132-170$.

Meyer, J.-W. (1997). Djebelet el-Beda: Eine Stätte der Abnenverehrung? Altorientalische Forschungen 24: 294-309.

Meyer, J.-W. (2006). Zur Chronologie von Tell Chuera. Baghdader Mitteilungen 37: 329-335.

Milano, L. and Rova, E. (2000). Ceramic provinces and political borders in upper Mesopotamia in the late early dynastic period. In Graziani, S. (ed.) Studi sul vicino oriente antico dedicati alla memoria di Luigi Cagni, Instituto Universitario Orientale, Naples, pp. 709749.

Moorgat-Correns, U. (2001). Der Tell Chuera im Rückblick. Altorientalische Forschungen 28: 353-388. 
Munchaev, R. M. and Merpert, N. Y. (1998). Tell Hazna I, the most ancient cult centre in northeast Syria. In Arsebük, G., Mellink, M. J. and Schirmer, W. (eds.), Light on the Top of the Black Hill: Studies Presented to Halet Çambel, Ege Yayinlari, Istanbul, pp. 499-514.

Nicolle, C. (ed.) (2004). Nomades et sédentaires dans le Proche-Orient ancient: compte rendu de la XLVIe Rencontre assyriologique internationale, Editions Recherche sur les civilisations, Paris.

Nicolle, C. (2006). Tell Mohammed Diyab 3: Travaux de 1992-2000 sur les buttes A et B, Editions Recherche sur les Civilisations, Paris.

Oates, D. and Oates, J. (2006). Ebla and Nagar. In Baffi, F., Dolce, R., Mazzoni, S. and Pinnock, F. (eds.), Ina kibret erbetti. Studi di Archeologia orientale dedicati a Paolo Matthiae, Università di Roma La Sapienza, Rome, pp. 399-423.

Oguchi, H. (2003). 20th century B.C. north Mesopotamia: An archaeological dilemma. AlRafidan 24: 83-100.

Orthmann, W. (ed.) (1995). Ausgrabungen in Tell Chuera in Nordost-Syrien I: Vorbericht über die Grabungskampagnen 1986 bis 1992, Saarbrücker Druckerei und Verlag, Saarbrücken.

Pfälzner, P. (2008). Redistributive, kommunale und häusliche Vorratshaltung am Unteren Habur im 3. Jtsd. v. Chr. In Kühne, H. (ed.) Umwelt und Subsistenz der assyrischen Stadt DūrKatlimmu am unteren Hābūr, Harrassowitz, Wiesbaden, pp. 163-179.

Pollock, S. and Coursey, C. (1995). Ceramics from Hacinebi Tepe: Chronology and connections. Anatolica 21: 101-141.

Porter, A. (1995). The third millennium settlement complex at Tell Banat: Tell Kabir. Damaszener Mitteilungen 8: 125-164. 
Porter, A. (2002). Communities in conflict: Death and the contest for social order in the Euphrates river valley. Near Eastern Archaeology 65: 156-173.

Porter, A. (2007). The ceramic assemblages of the third millennium in the Euphrates region. In al-Maqdissi, M., Matoiän, V. and Nicolle, C. (eds.), La céramique du l'âge du Bronze en Syrie II: L'Euphrate et la région de Jézireh, IFAPO, Damascus, pp. 3-22.

Porter, A. (2007). You say potato, I say... Typology, chronology and the origins of the Amorites. In Kuzucuoğlu, C. and Marro, C. (eds.), Sociétés humaines et changement climatique à la fin du troisième millénaire: une crise a-t-elle eu lieu en haute Mésopotamie?, Institut Français d'études anatoliennes Georges-Dumézil, Istanbul, pp. 69-115.

Porter, A. (in press). From kin to class-and back again: Changing paradigms of the early polity. In MacGuire, L. and Bolger, D. (eds.), The Development of Pre-State Communities in the Ancient Near East: Studies in Honour of Edgar Peltenberg, Oxbow.

Pruß, A. and Sallaberger, W. (2003-2004). Tierhaltung in Nabada/Tell Beydar und die Bilderwelt der Terrakotten als Spiegel von Wirtschaft und Umvelt. Archiv für Orientforschung 50: 293-307.

Rainville, L. (2000). Microdebris analysis in bronze age Mesopotamian households. Antiquity 74: 284 .

Riehl, S., Bryson, R. and Pustovoytov, K. (2008). Changing growing conditions for crops during the Near Eastern bronze age (3000-1200 BC): The stable carbon isotope evidence. Journal of Archaeological Science 35: 1011-1022.

Ristvet, L. (2005). Settlement, Economy, and Society in the Tell Leilan Region, Syria, 3000-1000 $B C$, Ph.D. dissertation, Faculty of Oriental Studies, University of Cambridge, Cambridge. 
Ristvet, L. (2007). The third millennium city wall at Tell Leilan, Syria: Identity, authority, and urbanism. In Bretschneider, J., Driessen, J. and van Lerberghe, K. (eds.), Power and Architecture: Monumental Public Architecture in the Bronze Age Near East and Aegean, Peeters, Leuven, pp. 183-211.

Roaf, M. (2003). The architecture of the Ninevite 5 period. In Rova, E. and Weiss, H. (eds.), The Origins of North Mesopotamian Civilization: Ninevite 5 Chronology, Economy, Society, Brepols, Turnhout, pp. 311-333.

Rouault, O. and Wäfler, M. (eds.) (2000). La Djéziré et l'Euphrate syriens de la protohistoire à la fin du Ile millénaire av. J.-C.: Tendances dans l'interprétation historique des données nouvelles, Brepols, Turnhout.

Rova, E. (1999-2000). A tentative synchronisation of the local late chalcolithic ceramic horizons of northern Syro-Mesopotamia. Mesopotamia 34-35: 175-199.

Sallaberger, W. (2007). From urban culture to nomadism: A history of upper Mesopotamia in the late third millennium. In Kuzucuoğlu, C. and Marro, C. (eds.), Sociétés humaines et changement climatique à la fin du troisième millénaire: une crise a-t-elle eu lieu en haute Mésopotamie?, Institut Français d'études anatoliennes Georges-Dumézil, Istanbul, pp. 417-456.

Sallaberger, W. and Ur, J. A. (2004). Tell Beydar/Nabada in its regional setting. In Milano, L., Sallaberger, W., Talon, P. and Van Lerberghe, K. (eds.), Third Millennium Cuneiform Texts from Tell Beydar (Seasons 1996-2002), Brepols, Turnhout, pp. 51-71.

Schwartz, G. M. (2003). Socio-political developments in the Ninevite 5 period. In Rova, E. and Weiss, H. (eds.), The Origins of North Mesopotamian Civilization: Ninevite 5 Chronology, Economy, Society, Brepols, Turnhout, pp. 585-592. 
Schwartz, G. M. (2007). Hidden tombs of ancient Syria. Natural History 116: 42-47.

Schwartz, G. M., Curvers, H. H. and Stuart, B. (2000). A 3rd-millennium BC elite tomb from Tell Umm el-Marra, Syria. Antiquity 74: 771-772.

Schwartz, G. M. and Miller, N. F. (2007). The 'crisis' of the late third millennium B.C: Ecofactual and artifactual evidence from Umm el-Marra and the Jabbul plain. In Kuzucuoğlu, C. and Marro, C. (eds.), Sociétés humaines et changement climatique à la fin du troisième millénaire: une crise a-t-elle eu lieu en haute Mésopotamie?, Institut Français d'études anatoliennes Georges-Dumézil, Istanbul, pp. 179-203.

Soltysiak, A. (2008). Tell Majnuna (Syria) season 2006. Bioarchaeology of the Near East 2: 7794.

Stein, G. J. (2000). Material culture and social identity: The evidence for a 4th millennium BC Mesopotamian Uruk colony at Hacinebi, Turkey. Paléorient 25: 11-22.

Strommenger, E. and Kohlmeyer, K. (2000). Ausgrabungen in Tall Bi'a/Tuttul III: Die Schichten des 3. Jahrtausends v. Chr. im Zentralhügel E, Saarbrückener Druckerei und Verlag, Saarbrücken.

Valentini, S. (2005). La ceramica protodynastica dell'area G. In Pecorella, P. E. and Pierobon Benoit, R., Tell Barri/Kahat: La Campagna del 2002. Firenze University Press, Florence, pp. 181-190.

van Loon, M. N. (ed.) (2001). Selenkahiye: Final Report on the University of Chicago and University of Amsterdam Excavations in the Tabqa Reservoir, Northern Syria, 19671975, Nederlands Historisch-Archaeologisch Instituut te Istanbul, Istanbul.

Weber, J. (2006). Economic Developments of Urban Proportions: Evolving Systems of AnimalProduct Consumption and Distribution in the Early and Middle Bronze Ages in Syro- 
Mesopotamia, Ph.D. dissertation, Department of Anthropology, University of Pennsylvania, Philadelphia.

Wilkinson, T. J. (2000). Archaeological survey of the Tell Beydar region, Syria, 1997: A preliminary report. In Van Lerberghe, K. and Voet, G. (eds.), Tell Beydar: Environmental and Technical Studies, BREPOLS, Turnhout.

Wilkinson, T. J. (2002). The settlement transition of the second millennium BC in the western Khabur. In al-Gailani Werr, L., Curtis, J., Martin, H., McMahon, A., Oates, J. and Reade, J. (eds.), Of Pots and Plans: Papers on the Archaeology and History of Mesopotamia and Syria Presented to David Oates in Honour of his 75th Birthday, Nabu Publications, pp. $361-372$.

Wilkinson, T. J. (2005). Approaches to modelling archaeological site territories in the Near East. In Beekman, C. S. and Baden, W. W. (eds.), Nonlinear Models for Archaeology and Anthropology, Ashgate, Hampshire, pp. 123-138.

Wilkinson, T. J. (2007). Archaeological regions in the neighborhood of Carchemish. In Peltenburg, E. (ed.) Euphrates River Valley Settlement: The Carchemish Sector in the Third Millennium BC, Oxbow, Oxford, pp. 27-42.

Yardımcı, N. (2004). Harran Ovası yüzey araştırmasl, A. Grafik ve Matbaacılık San., Istanbul. Zeder, M. (1994). After the revolution: Post-Neolithic subsistence strategies in northern Mesopotamia. American Anthropologist 96: 97-126.

Zeder, M. (1995). The archaeobiology of the Khabur basin. Bulletin of the Canadian Society for Mesopotamian Studies 29: 21-32. 


\section{Figures}

Figure 1. Geography and major sites of northern Mesopotamia. Dam zones in caps.

Figure 2. Schematic illustration of the scale and distribution of urban places in southern and northern Mesopotamia, 5000-2000 BC. Points with solid outlines are extensive "proto-urban" settlements.

\section{Tables}

Table I. Chronologies used in Mesopotamian archaeology (based on Akkermans and Schwartz 2003; Cooper 2006, pp. 6-26; Lebeau 2000; Oates et al. 2001 Table 1; Wright and Rupley 2001). 


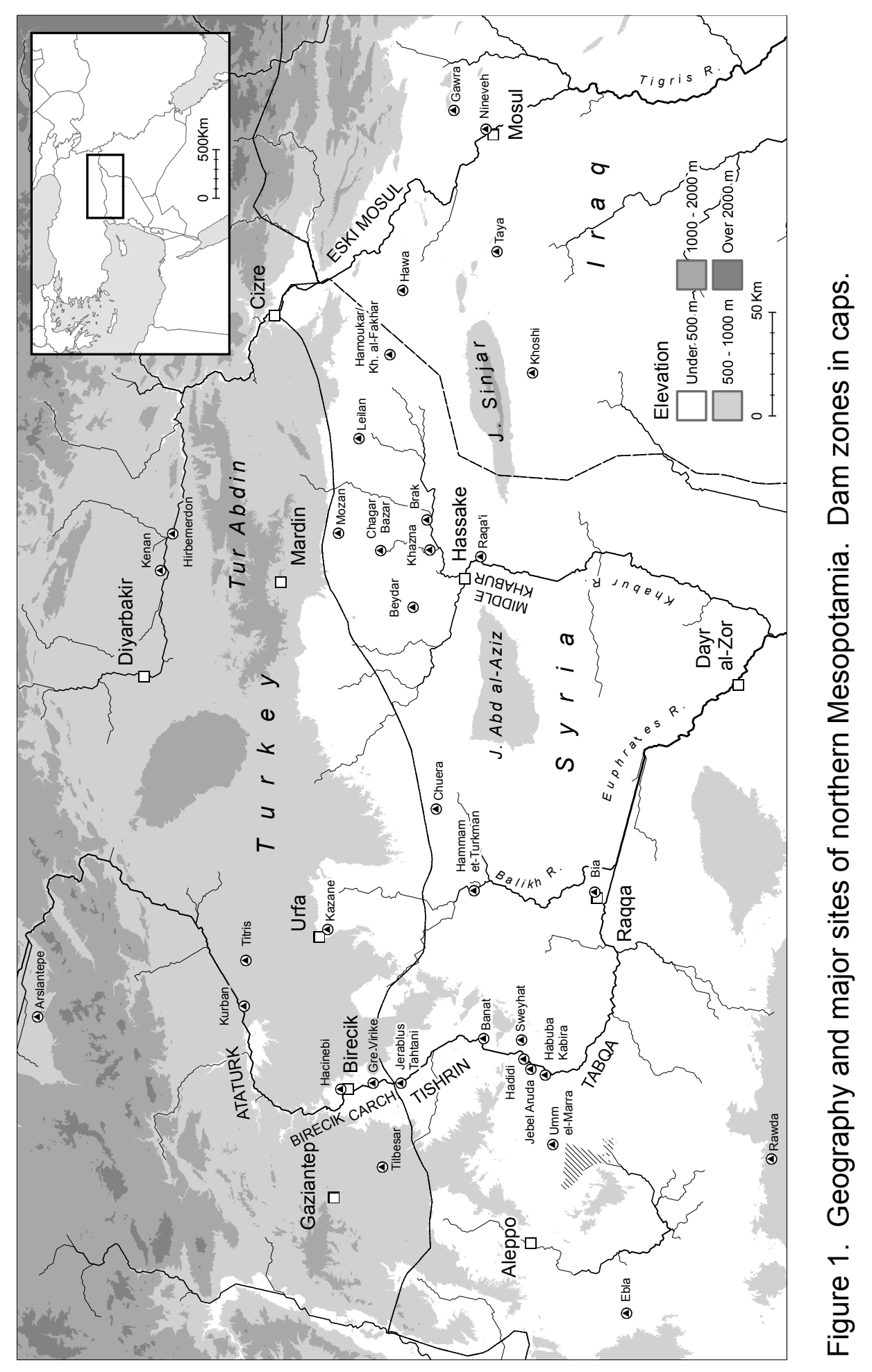




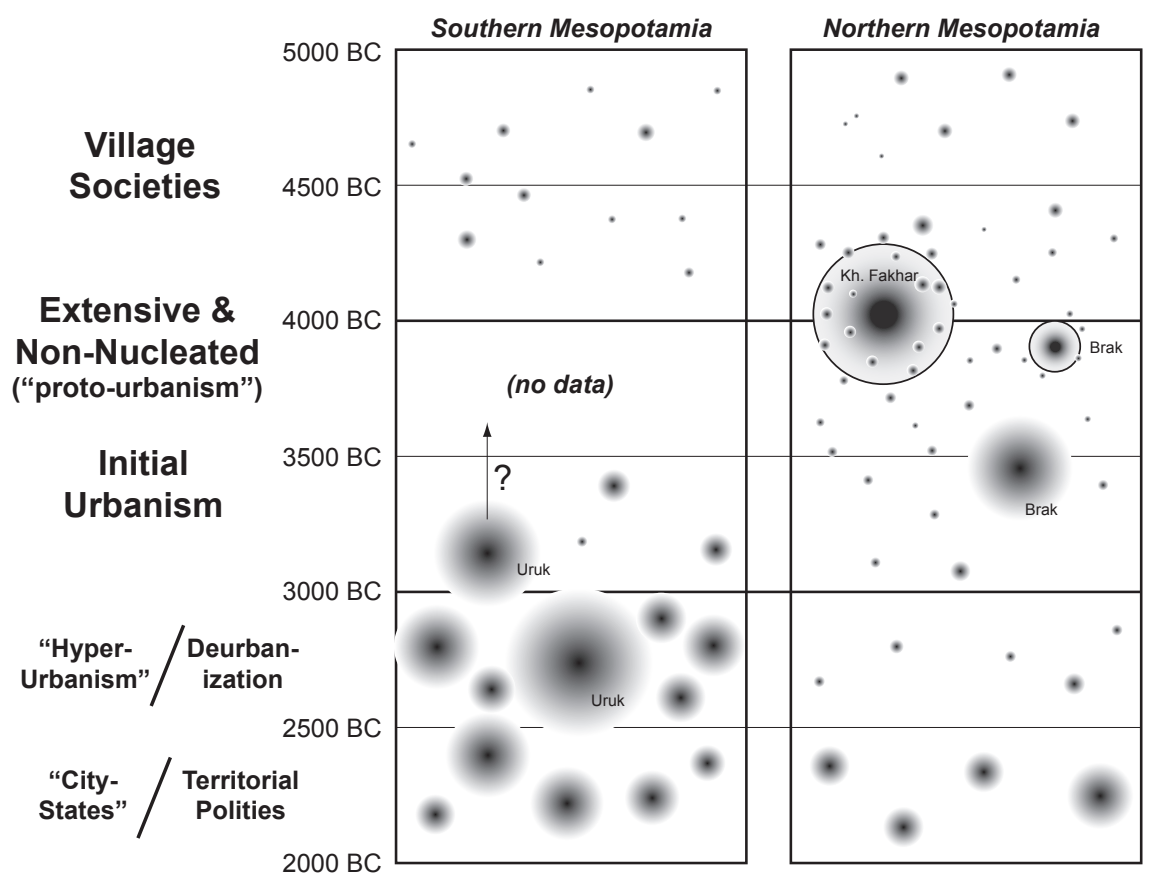

Figure 2. Schematic illustration of the scale and distribution of urban places in southern and northern Mesopotamia, 50002000 BC. Points with solid outlines are extensive "protourban" settlements. 


\begin{tabular}{|c|c|c|c|c|c|c|c|c|}
\hline \multirow{2}{*}{\multicolumn{2}{|c|}{ Absolute Dates }} & \multirow{2}{*}{$\begin{array}{c}\text { LC/ } \\
\text { Early Jazira } \\
\end{array}$} & \multirow{2}{*}{$\begin{array}{c}\text { Southern } \\
\text { Mesopotamia }\end{array}$} & \multicolumn{3}{|c|}{ Northern Mesopotamia } & \multirow{2}{*}{ Amuq } & \multirow{2}{*}{$\begin{array}{c}\text { Porter/Cooper } \\
\text { N Euphrates }\end{array}$} \\
\hline & & & & Traditional & Brak & Leilan & & \\
\hline \multirow{14}{*}{ 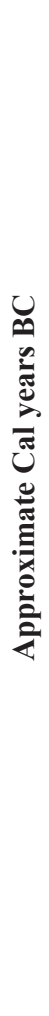 } & $5200-4400$ & & Ubaid & Northern Ubaid & $\mathrm{C}$ & & \multirow{7}{*}{$\mathrm{F}$} & \multirow{14}{*}{$\begin{array}{l}\text { Phase } 2 \\
\text { Phase } 3\end{array}$} \\
\hline & $4400-4100$ & $\mathrm{LC} 1$ & Late Ubaid & Terminal Ubaid & $\mathrm{D}$ & VIb & & \\
\hline & $4100-3800$ & $\mathrm{LC} 2$ & Early Uruk & Northern Early Uruk & E & & & \\
\hline & $3800-3600$ & LC3 & \multirow{2}{*}{ Middle Uruk } & Northern Middle Uruk & \multirow{2}{*}{$\mathrm{F}$} & $\mathrm{V}$ & & \\
\hline & $3600-3300$ & LC4 & & Middle Uruk & & & & \\
\hline & $3300-3000$ & LC5 & Late Uruk & Late Uruk & G & IV & & \\
\hline & $3000-2900$ & EJ 0 & \multirow{2}{*}{$\begin{array}{l}\text { Early Dynastic I } \\
\text { through early III }\end{array}$} & Post-Uruk & $\mathrm{H}$ & & & \\
\hline & $2900-2600$ & EJ I & & Ninevite 5 & $\mathrm{~J}$ & IIIa-c & \multirow{2}{*}{ G } & \\
\hline & $2600-2500$ & EJ II & \multicolumn{2}{|c|}{ Early Dynastic IIIa } & $\mathrm{K}$ & IIId & & \\
\hline & $2500-2300$ & EJ III & \multicolumn{2}{|c|}{ Early Dynastic IIIb } & $\mathrm{L}$ & IIa & \multirow{2}{*}{ I } & \\
\hline & $2300-2100$ & EJ IV & \multicolumn{2}{|c|}{ Akkadian } & M & $\mathrm{IIb}$ & & \\
\hline & $2100-2000$ & EJ V & Ur III & Post-Akkadian & \multirow{2}{*}{$\mathrm{N}$} & \multirow{2}{*}{$\begin{array}{c}\text { IIc/ } \\
\text { "Habur Hiatus" }\end{array}$} & \multirow{3}{*}{$\mathrm{J}$} & \\
\hline & $2000-1800$ & & Isin-Larsa & Middle Bronze I & & & & \\
\hline & $1800-1600$ & & Old Babylonian & $\begin{array}{c}\text { Middle Bronze II/ } \\
\text { Khabur }\end{array}$ & $\mathrm{P}$ & I & & \\
\hline
\end{tabular}

Table I. Chronologies used in Mesopotamian archaeology (based on Akkermans and Schwartz 2003; Cooper 2006, pp. 6-26; Lebeau 2000; Oates et al. 2001 Table 1; Wright and Rupley 2001). 